\title{
Effect of crowding stress and /or sulpiride treatment on some physiological and histological parameters in female albino rats.
}

\author{
Fatma Eid*, Eman G.E.Helal **,Neama M.Taha. ** \\ Zoology Department ,Faculty of Science,Al-Azhar University. \\ (Histology*,Physiology**)
}

\begin{abstract}
Background: Crowding is the most stressful factor on human being. So these studies aimed to clarify effect on some physiological and histological parameters.

Material and methods: 36 Female rats were divided into four groups (6/each):1-control, 2treated with sulpiride drug, 3 - crowded exposure 4- crowded + drug .

Results: drug recorded a significant increase only in the percentage of body weight gain but the other parameters showed no significant changes. Stress recorded a significant increase in glucose, ALT, GGT, TP, globulin, creatinine, total lipids, TG, cholesterol, HDL-C, LDL-C. A significant decrease in percentage of body weight gain and $\mathrm{A} / \mathrm{G}$ ratio were also detected. Sulpiride drug ameliorated most of these parameters.

Concerning the histological and histochemical studies sulpiride treatment showed no detectable changes in the kidney and liver tissues with exception of increased lymphocytes. Exposure to crowding showed many dystrophic changes in both tissue, but drug treatment improved all the previous changes and this indicates the protective effect of sulpiride against crowding exposure.
\end{abstract}

Conclusion: it is useful to use sulpiride drug in people who exposed to crowded stress.

Key words: Crowding, Sulpiride drug, Albino rats, Physiological parameters, Histopathology and histochemistery.

\section{Introduction}

Crowding stress is a type of psychosocial stress induced by an increased density of population. Population density may be raised either by increasing the number of species living in the same area and/or by reducing their living space. Crowding stress induces complex changes at the behavioral, physiological and molecular levels (Benyo et al.,2007). Antidepressant drugs are the most successful drug in patients with clearly (vegetative) characteristics including psychomotor retardation, sleep disturbance, poor appetite and weight loss. However, a variety of different chemical structures have been found to have antidepressant activity. Their number is constantly growing, but as yet no group has been found to have a clear therapeutic advantage over the others (Katzung ,2008). Sulpiride is the most favorite drug which used to tolerate stress symptom (Panzani et al.,2011). People which expose to stress take one or some drugs to avoid the effect of stress even without a doctor prescription. So, in this study we try to illustrate the effect of one of the antidepressant drugs (sulpiride) which generally used by people to avoid the effect of stress. The present study deals with the possible protective effect of sulpiride against crowded in female albino rats from the physiological, histological and histochemical point of view. 


\section{Material and Methods}

\section{Material:}

\section{1-Experimental animals:}

24 Normal white female albino rats weighing ( $150 \pm 30)$ gms were taken from the farm of National organization for the experiment .They were kept under observation for one week before the beginning of the experiment to acclimatize .The chosen animals were housed in cages and exposed to artificial light for $14 \mathrm{hrs}$ and $10 \mathrm{hrs}$ complete darkness at normal atmospheric temperature .All animals were fed on standard diet contained protein, fibers , fats , ash, carbohydrates and supplied with vitamins and minerals mixture with continuous supply of water.

\section{2-Sulpiride administration:}

The drug was adiministrated orally by gastric tube at a dose of $0.028 \mathrm{mg} / \mathrm{g}$ body weigh/day for one month .The dose for the rat was calculated according to the paget's formula on the basis of the human dose(Paget and Barns,1964).

\section{Methods:}

\section{(I) Animal groups:}

24 female albino rats were divided into 4 main groups each group contained 6 rats. Group1:

Normal rats served as negative control (without any treatment for one month-in cage

$$
20 \times 30 \times 20) \text {. }
$$

\section{Group 2:}

Rats treated with the sulpiride drug at adose of $(0.28 \mathrm{mg} / 100 \mathrm{mg}$ body weigh/day for one month.)

\section{Group 3:}

Rats exposed to crowding only for one month

\section{Group 4:}

Rats exposed to crowding and treated with the drug for one month.
Application of crowding:

Each 6 rats were but in a cage $(20 \times 20 \times 20$ $\mathrm{cm})$

\section{(II) Morphological studies:}

\section{Body weight:}

Each rat was weighted at the beginning and the end of the experiment. Percentage of body weight changes was calculated.

After one month, rats were scarified and blood was taken and put in centrifuge tube and centrifuged to obtained serum for the following examinations.

\section{Physiological studies}

Serum glucose was estimated according to method described by Tietz (1995) . Aspartate aminotransferase (AST) and alanine aminotransferase (ALT) activity were estimated according to the method of Schumann( 2002),serum albumin and total protein (TP) level were measured according to the method of Burtis et al .(2006) serum alkaline phosphatase was measured according to the method of Abicht et al .(2001), serum gammagluttamyl transferase (GGT) activity was done using the method of Kytzia (2005) 2 serum total Bilirubin was measured according to the method of Tietz (1995).

Serum urea and creatinine were measured according to the method of Junge et $\boldsymbol{a l . ( 2 0 0 4 )}$, serum uric acid was done using the method of Tietz (2006). Total lipid concentration was done according to the method of Knight et al.(1972), serum cholesterol level was measured according to the method of Tietz ( 1995),serum Triglycerides(TG) was done according to the method of Stein and Myers(1995), serum HDL-cholesterol and LDL-C were measured according to method of Sugiuchi (2005).

\section{Data analysis:}

The obtained results were statistically analyzed by using the student ( $\mathrm{T}$ test) according to the method of Snedecor and Cochran (1980)., $\quad \mathrm{P}<0.05 \quad$ considerd significant while $\mathrm{P}<0.01$ highly significant. 
Histological and histochmical studies:

Control and treated rats were sacrificed after an month and small pieces of liver and kidney were taken for the histological and histochemical studies .Small pieces of liver and kidney were fixed in $10 \%$ neutral buffered forml solution and Carnoy's fluid for the histological and histochemical studies .Paraffin section were prepared
$5 \mu \mathrm{m}$ thickness and stained with Harris haematoxylin and eosin (Drury and Wallington, 1980). Proteins were detected by mercuric bromophenol blue method (Mazia et al.,1953).Polysaccharides were detected by PAS (periodic acSchiff)method (Pearse,1977).Mallory's trichome stain for demonstrating collagen fibers (Pearse, 1977).

\section{Results}

Table (1): Percentage of body weight change in female albino rats after exposed to stress (crowd), sulpiride, dual effect.

\begin{tabular}{|c|c|c|c|c|c|}
\hline \multirow{2}{*}{\multicolumn{2}{|c|}{ parameter }} & \multirow{3}{*}{$\begin{array}{c}\text { control } \\
57.2\end{array}$} & \multirow{3}{*}{$\begin{array}{r}\text { drug } \\
156\end{array}$} & \multirow{3}{*}{$\begin{array}{c}\text { crowd } \\
15.8\end{array}$} & \multirow{3}{*}{$\begin{array}{c}\begin{array}{c}\text { Crowd } \\
\text { +drug }\end{array} \\
26.5\end{array}$} \\
\hline & & & & & \\
\hline \multirow{3}{*}{$\begin{array}{r}\text { Bodyweight } \\
\text { change }\end{array}$} & Mean & & & & \\
\hline & \pm SE & 1.6 & 2.5 & 1.7 & 0.8 \\
\hline & $\mathbf{P}$ & & $<0.01$ & $<0.01$ & $<0.01$ \\
\hline \multicolumn{2}{|c|}{ \%Of change } & & 172.7 & -72.3 & -53.6 \\
\hline
\end{tabular}

In table (1) rats treated with sulpiride drug alone showed highly body weight gain $(\mathrm{P}<0.01)$. On the other hand, crowding exposure group or crowding exposure and treated with sulpiride recorded highly significant body weight lose $(\mathrm{P}<0.01)$.

Rats treated with sulpiride drug alone showed no significant change on all the present biochemical Parameters (except creatinine)

Table (2): Serum glucose level ( $\mathrm{mg} / \mathrm{dl}$ ) in female albino rats after exposed to stress (crowd) sulpiride, dual effect.

\begin{tabular}{|c|c|c|c|c|c|}
\hline \multicolumn{2}{|c|}{ parameter } & \multirow{2}{*}{$\begin{array}{c}\text { control } \\
101.7\end{array}$} & \multirow{2}{*}{$\begin{array}{l}\text { drug } \\
94.8\end{array}$} & \multirow{2}{*}{$\begin{array}{c}\text { crowd } \\
134.0\end{array}$} & \multirow{2}{*}{$\begin{array}{c}\begin{array}{c}\text { Crowd } \\
\text { +drug }\end{array} \\
124\end{array}$} \\
\hline \multirow{3}{*}{$\begin{array}{l}\text { Glucose } \\
\text { (mg/dl) }\end{array}$} & Mean & & & & \\
\hline & $\pm \mathbf{S E}$ & 1.3 & 1.98 & 1.9 & 1.6 \\
\hline & $\mathbf{P}$ & & N.S & $<0.01$ & $<0.01$ \\
\hline \multicolumn{2}{|c|}{$\%$ Of change } & & -6.8 & 31.7 & 22.7 \\
\hline
\end{tabular}

Table (2) crowding exposure group or crowding exposure and treated with sulpiride recorded showed highly significant increase $(\mathrm{P}<0.01)$ in glucose level when compared with control group. 
Table (3): Serum (ALT) activity (u/l) in female albino rats after exposed to stress (crowd) sulpiride, dual effect.

\begin{tabular}{|c|c|c|c|c|c|}
\hline \multicolumn{2}{|r|}{ Group } & control & drug & crowd & $\begin{array}{c}\text { Crowd } \\
\text { +drug }\end{array}$ \\
\hline \multirow{3}{*}{$\begin{array}{c}\text { ALT } \\
\text { parameter }\end{array}$} & Mean & 39.6 & 39.1 & 59.3 & 49.5 \\
\cline { 2 - 6 } & \pm SE & 3.1 & 0.6 & 3.0 & 1.34 \\
\cline { 2 - 6 } & $\mathbf{P}$ & & N.S & $<0.01$ & $<0.05$ \\
\hline \multicolumn{2}{|r|}{$\%$ Of change } & & -1.2 & 49.7 & 25 \\
\hline
\end{tabular}

Data represented in table (3) showed that rats treated with sulpiride drug alone caused no significant change in (ALT) . On the other hand, crowding exposure group or crowding exposure and treated with sulpiride recorded highly significant increase $(\mathrm{P}<0.01)$ of the (ALT) activity when compared with control group .

Regarding AST, ALP, activities, Bil level, no significant change were recorded in all groups (tables 4, 5, 6).

Table (4): Serum (AST) activity (u/l) in female albino rats after exposed to stress (crowd) sulpiride, dual effect.

\begin{tabular}{|c|c|c|c|c|c|}
\hline \multicolumn{2}{|r|}{} & control & drug & crowd & $\begin{array}{c}\text { Group } \\
\text { Crowd } \\
\text { +drug }\end{array}$ \\
\hline \multirow{2}{*}{$\begin{array}{c}\text { AST } \\
\text { parameter }\end{array}$} & Mean & 28.0 & 22.5 & 31.6 & 26.2 \\
\cline { 2 - 6 } & \pm SE & 4.9 & 3.0 & 3.2 & 3.5 \\
\cline { 2 - 7 } & P & & N.S & N.S & N.S \\
\hline \multicolumn{2}{|r|}{$\%$ Of change } & & -19.6 & 12.8 & -6.4 \\
\hline
\end{tabular}

Table (5): Serum (ALP) activity (u/l)) in female albino rats after exposed to stress (crowd) sulpiride, dual effect.

\begin{tabular}{|c|c|c|c|c|c|}
\hline \multicolumn{2}{|r|}{} & Group & & & \\
parameter & control & drug & crowd & $\begin{array}{c}\text { Crowd } \\
\text { +drug }\end{array}$ \\
\hline \multirow{2}{*}{ ALP } & Mean & 74.3 & 72.8 & 70.6 & 68.5 \\
\cline { 2 - 6 }$(\mathbf{u} / \mathbf{l})$ & \pm SE & 3.0 & 3.1 & 2.4 & 1.2 \\
\cline { 2 - 6 } & $\mathbf{P}$ & & N.S & N.S & N.S \\
\hline \multicolumn{2}{|r|}{$\%$ Of change } & & -2.0 & -4.9 & -7.8 \\
\hline
\end{tabular}


Fatma Eid... et al

Table (6): Serum (BIL)level ( $\mathrm{mg} / \mathrm{dl}$ ) in female albino rats after exposed to stress (crowd) sulpiride, dual effect.

\begin{tabular}{|c|c|c|c|c|c|}
\hline \multicolumn{2}{|l|}{ parameter } & control & drug & crowd & $\begin{array}{l}\text { Crowd } \\
+ \text { drug }\end{array}$ \\
\hline \multirow{3}{*}{$\begin{array}{c}\text { BIL } \\
(\mathbf{m g} / \mathrm{dl})\end{array}$} & Mean & 0.3 & 0.3 & 0.3 & 0.3 \\
\hline & $\pm \mathbf{S E}$ & 0.07 & 0.09 & 0.072 & 0.05 \\
\hline & $\mathbf{P}$ & & N.S & N.S & N.S \\
\hline \multicolumn{2}{|c|}{ \%Of change } & & $\mathbf{0}$ & $\mathbf{0}$ & $\mathbf{0}$ \\
\hline
\end{tabular}

Table (7): Serum (GGT)level $(u / l))$ in female albino rats after exposed to stress (crowd) sulpiride, dual effect.

\begin{tabular}{|c|c|c|c|c|c|}
\hline \multicolumn{2}{|c|}{ parameter } & control & drug & crowd & $\begin{array}{l}\text { Crowd } \\
+ \text { drug }\end{array}$ \\
\hline \multirow{3}{*}{$\begin{array}{c}\text { GGT } \\
(\mathbf{u} / \mathbf{l})\end{array}$} & Mean & 21.35 & 20.0 & 30.3 & 24.0 \\
\hline & $\pm \mathbf{S E}$ & 0.86 & 0.6 & 1.37 & 0.6 \\
\hline & $\mathbf{P}$ & & N.S & $<0.01$ & $<0.05$ \\
\hline \multicolumn{2}{|c|}{ \%Of change } & & -6.3 & 41.92 & 14.7 \\
\hline
\end{tabular}

In table (7) Crowding exposure group showed highly significant increase $(\mathrm{P}<0.01)$ in ( GGT) but crowding exposure and treated with sulpiride showed significant increase $(\mathrm{P}<0.05)$ when compared with control group. 

Table (8): Serum (TP) level ( $\mathrm{g} / \mathrm{dl}$ ) in female albino rats after exposed to stress (crowd) sulpiride, dual effect.

\begin{tabular}{|c|c|c|c|c|c|}
\hline$\times$ & Grou & control & drug & crowd & $\begin{array}{l}\text { Crowd } \\
+ \text { drug }\end{array}$ \\
\hline \multirow{3}{*}{$\underset{(\mathrm{g} / \mathrm{dl})}{\mathbf{T P}}$} & Mean & 6.96 & 6.61 & 7.6 & 7.1 \\
\hline & $\pm \mathbf{S E}$ & 0.1 & 0.2 & 0.16 & 0.2 \\
\hline & $\mathbf{P}$ & & N.S & $<0.01$ & N.S \\
\hline \multicolumn{2}{|c|}{$\%$ Of change } & & 5.0 & 9.1 & 2.0 \\
\hline
\end{tabular}

Data represented in table (8) showed crowding group highly significant increase $(\mathrm{P}<0.01)$ of the (TP) level when compared with control group while treating stressed rat with sulpiride truned TP back to its normal level.

Regarding Albumin no significant change were recorded in all groups (table 9).

Table (9): Serum (Albumin)level ( $g / d l)$ in female albino rats after exposed to stress (crowed) sulpiride, dual effect.

\begin{tabular}{|c|c|c|c|c|c|}
\hline$\times$ & Grou & control & drug & crowd & $\begin{array}{l}\text { Crowd } \\
+ \text { drug }\end{array}$ \\
\hline \multirow{3}{*}{$\begin{array}{l}\text { Albumin } \\
\text { (g/dl) }\end{array}$} & Mean & 4.21 & 3.9 & 3.7 & 3.7 \\
\hline & $\pm \mathbf{S E}$ & 0.3 & 0.2 & 0.1 & 0.2 \\
\hline & $\mathbf{P}$ & & N.S & N.S & N.S \\
\hline \multicolumn{2}{|c|}{$\%$ Of change } & & -7.3 & -12 & -12 \\
\hline
\end{tabular}

Table (10): Serum (Globulin)level (dl) in female albino rats after exposed to stress (crowd) sulpiride, dual effect.

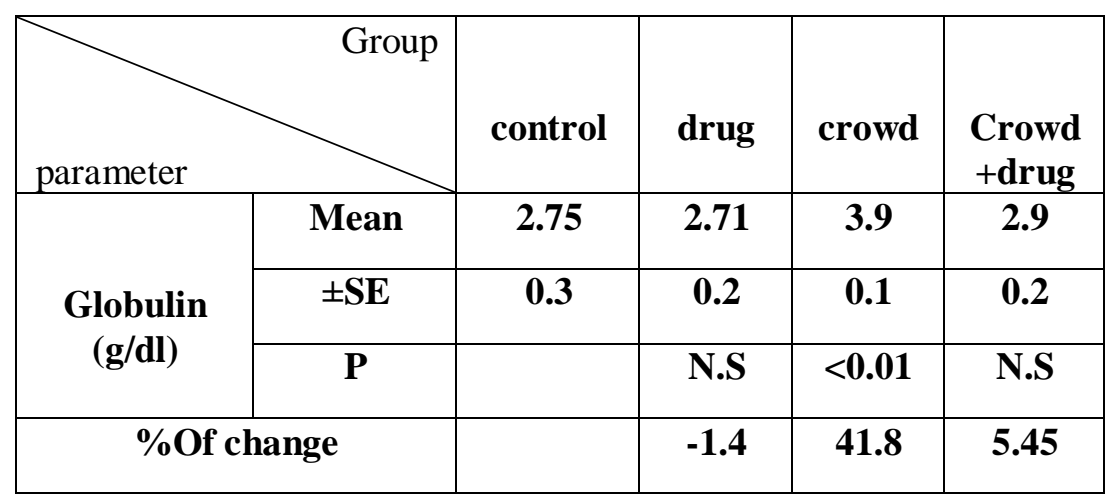

Rats exposed to crowding showed highly significant increase $(\mathrm{P}<0.01)$ of the (Globulin) level these increase turned back to normal value when rats treated with sulpiride in table (10) 
Fatma Eid... et al

Table (11): Serum (A/G Ratio) level in female albino rats after exposed to stress (crowd) sulpiride, dual effect.

\begin{tabular}{|c|c|c|c|c|c|}
\hline \multicolumn{2}{|r|}{ Group } & control & drug & crowd & $\begin{array}{c}\text { Crowd } \\
+ \text { drug }\end{array}$ \\
\hline \multirow{3}{*}{ A/G Ratio } & Mean & 1.53 & 1.43 & 0.95 & 1.2 \\
\cline { 2 - 6 } & \pm SE & 0.2 & 0.2 & 0.2 & 0.3 \\
\cline { 2 - 6 } & $\mathrm{P}$ & & $\mathrm{N.S}$ & $<0.05$ & N.S \\
\hline \multicolumn{2}{|r}{$\%$ Of change } & & -6.5 & -37.9 & -21.5 \\
\hline
\end{tabular}

In table (11) crowding exposure group recorded a significant decrease $(\mathrm{P}<0.05)$ in $(\mathrm{A} / \mathrm{G}$ Ratio) but sulpiride ameliorated this effect to the normal value in crowding exposure and treated with sulpiride.

Regarding Uric acid and Urea no significant change were recorded in all groups (table 12.13).

Table (12): serum Uric acid ( $\mathrm{mg} / \mathrm{dl})$ in female albino rats after exposed to stress (crowd) sulpiride, dual effect.

\begin{tabular}{|c|c|c|c|c|c|}
\hline$\times$ & Groul & control & drug & crowd & $\begin{array}{l}\text { Crowd } \\
+ \text { drug }\end{array}$ \\
\hline \multirow{3}{*}{$\begin{array}{c}\text { Uric acid } \\
\text { (mg/dl }\end{array}$} & Mean & 3.4 & 3.4 & 3.1 & 3.3 \\
\hline & $\pm \mathbf{S E}$ & 0.15 & 0.19 & 0.07 & 0.2 \\
\hline & $\mathbf{P}$ & & N.S & N.S & N.S \\
\hline \multicolumn{2}{|c|}{ \%Of change } & & 0 & $\begin{array}{l}-8.8 \\
\end{array}$ & -2.9 \\
\hline
\end{tabular}

Table (13): serum Urea level ( $\mathrm{mg} / \mathrm{dl})$ in female albino rats after exposed to stress (crowd) sulpiride, dual effect.

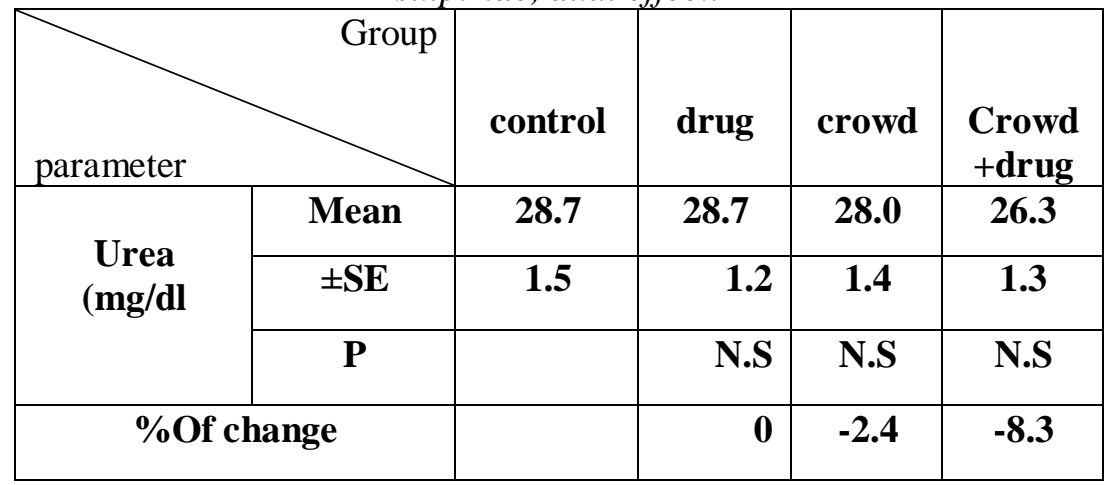


Effect of crowding ....

Table (14): serum Creatinine level ( $\mathrm{mg} / \mathrm{dl}$ ) in female albino rats after exposed to stress (crowd) sulpiride, dual effect.

\begin{tabular}{|c|c|c|c|c|c|}
\hline$\times$ & Group & control & drug & crowd & $\begin{array}{l}\text { Crowd } \\
\text { +drug }\end{array}$ \\
\hline \multirow{3}{*}{$\begin{array}{c}\text { creatinine } \\
\text { (mg/dl }\end{array}$} & Mean & 0.55 & 0.48 & 1.8 & 1.7 \\
\hline & $\pm \mathrm{SE}$ & 0.04 & 0.01 & 0.2 & 0.3 \\
\hline & $\mathbf{P}$ & & N.S & $<0.05$ & $<0.05$ \\
\hline \multicolumn{2}{|c|}{ \%Of change } & & -11.7 & 208 & 191 \\
\hline
\end{tabular}

Both groups of rats (exposed to crowding or crowding + drug)showed significant increase $(\mathrm{P}<0.05)$ when compared with control group(Table 14$)$.

Table (15): serum Total lipid level ( $\mathrm{mg} / \mathrm{dl}$ ) in female albino rats after exposed to stress (crowd) sulpiride, dual effect.

\begin{tabular}{|c|c|c|c|c|c|}
\hline \multicolumn{2}{|r|}{ Group } & control & drug & crowd & $\begin{array}{c}\text { Crowd } \\
\text { +drug }\end{array}$ \\
\hline \multirow{2}{*}{$\begin{array}{c}\text { Total lipid } \\
\text { (g/dl }\end{array}$} & Mean & 197 & 195 & 212 & 202 \\
\cline { 2 - 6 } & $\mathbf{P S E}$ & 1.8 & 1.4 & 1.7 & 1.2 \\
\cline { 2 - 6 } & $\mathbf{P}$ & & $\mathbf{N . S}$ & $<0.01$ & $<0.05$ \\
\hline \multicolumn{2}{|r|}{$\%$ Of change } & & $\mathbf{- 1 . 0}$ & $\mathbf{7 . 6}$ & $\mathbf{2 . 5}$ \\
\hline
\end{tabular}

Table (15) crowding exposure group was highly significant increase $(\mathrm{P}<0.01)$ and crowding exposure and treated with sulpiride showed significant increase $(\mathrm{P}<0.05)$ when compared with control group.

Table (16): serum Triglycerides level $(\mathrm{mg} / \mathrm{dl})$ in female albino rats after exposed to stress (crowed) sulpiride, dual effect.

\begin{tabular}{|c|c|c|c|c|c|}
\hline \multicolumn{2}{|r|}{ Group } & control & drug & crowd & $\begin{array}{c}\text { Crowd } \\
\text { +drug }\end{array}$ \\
\hline \multirow{2}{*}{$\begin{array}{c}\text { Triglycerides } \\
(\mathrm{mg} / \mathrm{dl})\end{array}$} & Mean & 66.6 & 68.1 & 124.1 & 100 \\
\cline { 2 - 6 } & $\mathrm{P}$ & 1.5 & 1.2 & 1.4 & 1.3 \\
\cline { 2 - 6 } & $\mathrm{P}$ & $\mathrm{N.S}$ & $<0.01$ & $<0.01$ \\
\hline \multicolumn{2}{|r|}{$\%$ Of change } & & 2.2 & 86.3 & 50.1 \\
\hline
\end{tabular}


Table (17): serum Cholesterol ( $\mathrm{mg} / \mathrm{dl})$ level in female albino rats after exposed to stress (crowed) sulpiride, dual effect.

\begin{tabular}{|c|c|c|c|c|c|}
\hline \multicolumn{2}{|r|}{ Group } & control & drug & crowd & $\begin{array}{c}\text { Crowd } \\
\text { +drug }\end{array}$ \\
\hline parameter & Mean & 118.1 & 115 & 151.2 & 139.2 \\
\hline \multirow{2}{*}{$\begin{array}{c}\text { Cholesterol } \\
(\mathrm{mg} / \mathrm{dl})\end{array}$} & \pm SE & 1.9 & 1.4 & 1.7 & 1.2 \\
\cline { 2 - 6 } & $\mathrm{P}$ & & $\mathrm{N.S}$ & $<0.01$ & $<0.01$ \\
\hline \multicolumn{2}{|r|}{$\%$ Of change } & & -2.6 & 28.0 & 17.8 \\
\hline
\end{tabular}

Table (18): serum HDL-Cholesterol level ( $\mathrm{mg} / \mathrm{dl}$ ) in female albino rats after exposed to stress (crowed) sulpiride, dual effect.

\begin{tabular}{|c|c|c|c|c|c|}
\hline \multicolumn{2}{|r|}{} & control & drug & crowd & $\begin{array}{c}\text { Crowd } \\
\text { +drug }\end{array}$ \\
\hline parameter & Mean & 65.3 & $\mathbf{6 2 . 0}$ & $\mathbf{7 0 . 0}$ & $\mathbf{7 0 . 5}$ \\
\hline $\begin{array}{c}\text { HDL- } \\
\text { Cholesterol } \\
(\mathrm{mg} / \text { dl) }\end{array}$ & \pm SE & $\mathbf{1 . 6}$ & $\mathbf{1 . 6}$ & $\mathbf{0 . 6}$ & $\mathbf{1 . 5}$ \\
\cline { 2 - 6 } & $\mathbf{P}$ & & $\mathbf{N . S}$ & $<0.01$ & $<0.01$ \\
\hline \multicolumn{2}{|r|}{$\%$ Of change } & & $\mathbf{- 5 . 0}$ & 7.1 & 7.9 \\
\hline
\end{tabular}

Crowding exposure group or crowding exposure and treated with sulpiride recorded highly significant increase $(\mathrm{P}<0.01)$ in the (TG,HDL-C, LDL-C) level when compared with control group in tables $(16,17,18,19)$.

Table (19): serum LDL-Cholesterol ( $\mathrm{mg} / \mathrm{dl})$ level in female albino rats after exposed to stress (crowd) sulpiride, dual effect.

\begin{tabular}{|c|c|c|c|c|c|}
\hline \multicolumn{2}{|l|}{ parameter } & control & drug & crowd & $\begin{array}{l}\text { Crowd } \\
+ \text { drug }\end{array}$ \\
\hline \multirow{3}{*}{$\begin{array}{c}\text { LDL- } \\
\text { Cholesterol } \\
\text { (mg/dl) }\end{array}$} & Mean & 51.1 & 49.2 & 80.1 & 65.4 \\
\hline & $\pm \mathbf{S E}$ & 3.3 & 2.5 & 1.8 & 3.1 \\
\hline & $\mathbf{P}$ & & N.S & $<0.01$ & $<0.01$ \\
\hline \multicolumn{2}{|c|}{ \%Of change } & & -3.7 & 56.7 & 27.9 \\
\hline
\end{tabular}

Regarding LDL/HDL -Cholesterol no significant change were recorded in all groups (table 19). 
Table (20): serum LDL/HDL-Cholesterol ( $\mathrm{mg} / \mathrm{dl}$ ) level in female albino rats after exposed to stress (crowed) sulpiride, dual effect.

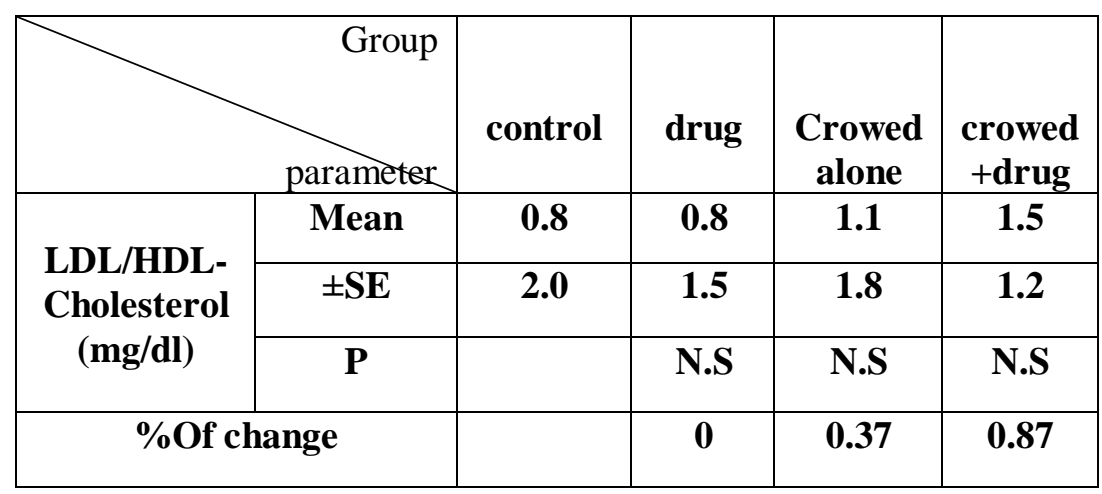

Drug treatment showed no detectable histological or histochemical changes in liver or kidney tissues with the exception of increased lymphocytes especially in the portal area of the liver and kidney tissues.

Exposure to crowding stress caused many pathological changes in the liver tissue of rats. These changes include: increased lymphocytes and Kupffer cells in the portal areas, dilated hpv and sinusoidal spaces, thickened arterial walls and ruptured endothelial lining of hpv which contained heamolysed RBCs and haemosidrin granules (Figs.3\&4) compared with the control group (Figs.1\&2). Highly increased collagen fibers in and around the portal area ,blood vessels and dilated sinusoidal spaces was observed in the liver tissue of rats exposed to crowding stresses (Figs.7\&8)compared with the control group (Figs.5\&6). Normal distribution of PSA+ ve materials was noticed in liver tissue of the control group (Figs.9\&10) Highly decreased PAS + ve materials were noticed in hepatocytes of the central and the portal areas of liver tissue of rats exposed to crowding. Homogenous red color of haemolysed RBCs inside the hpv was detected (Figs.11\&12). Decreased stain affinity of total protein was demonstrated in walls of bile canaliculi of liver tissue of rats exposed to crowding, but the thickened arterial wall was deeply stained (Figs.15\&16) compared with the control one (Figs.13\&14) .
Exposure of rats to crowding showed several dystrophic changes in the kidney tissue compared with the control group (Fig.17). These changes include: highly atrophied glomeruli , faintly stained cells and nuclei of the convoluted tubules with wide lamina of the distal ones, ruptured brush borders of the proximal ones, thickened arterial walls with branched and corrugated walls of the congested vein . Kidneys of group crowding + drug showed normal histological appearance .Increased collagen fibers were realized in the kidney tissue of crowding group (Fig.20) compared with the control group (Fig. 19). Also kidney tissue of group crowding + drug showed also increased collagen fibers in the convoluted tubules and Bowman's capsules (Fig.21) .Kidney tissue of crowding group showed poor stain affinity of PAS +ve materials in the haemolysed RBCs (Fig.23) with moderately stained tunica media and adventitia of the highly distorted renal artery compared with the control group (Fig.22) . Kidney of group crowding + drug showed normal stain affinity of PAS + ve materials. Poorly stained glomeruli of the kidney cortex of croding group were detected, but some of them were atrophied and deeply stained (Fig.25) compared with the control one (Fig.24), also convoluted tubules were faintly stained .Drug treatment post- exposure to crowding returned total protein to the normal level. 


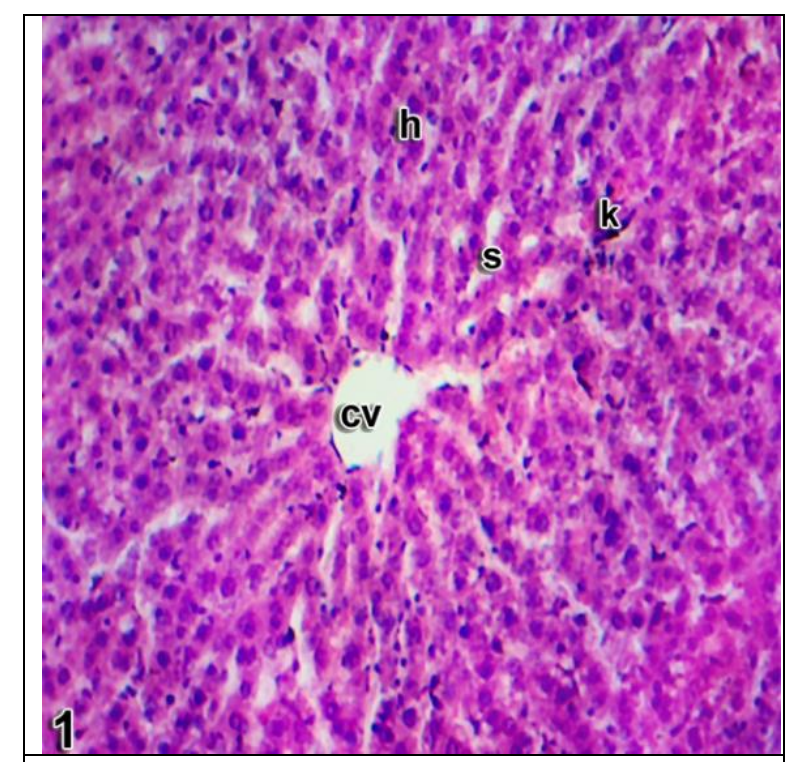

Figs(1\&2) showing photomicrogrs

of liver tissue of a control rat.

1-Showing the central areas of the liver tissue of a control rat.

1- Showing well developed hepatocytes (h) , sinusoidal spaces (s), central vein (cv)

and Kupffer cells (k) (HX\&Ex100)

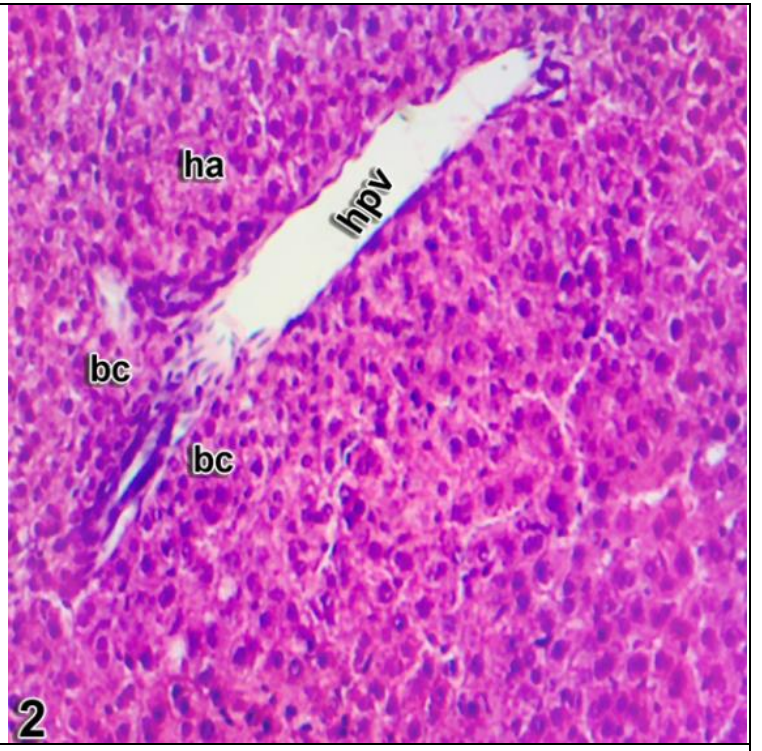

2-: Showing portal area which contains a branch of the hepatic portal vein (hpv), branch of the hepatic artery (ha) and bile canaliculi (bc) (HX\&Ex100)

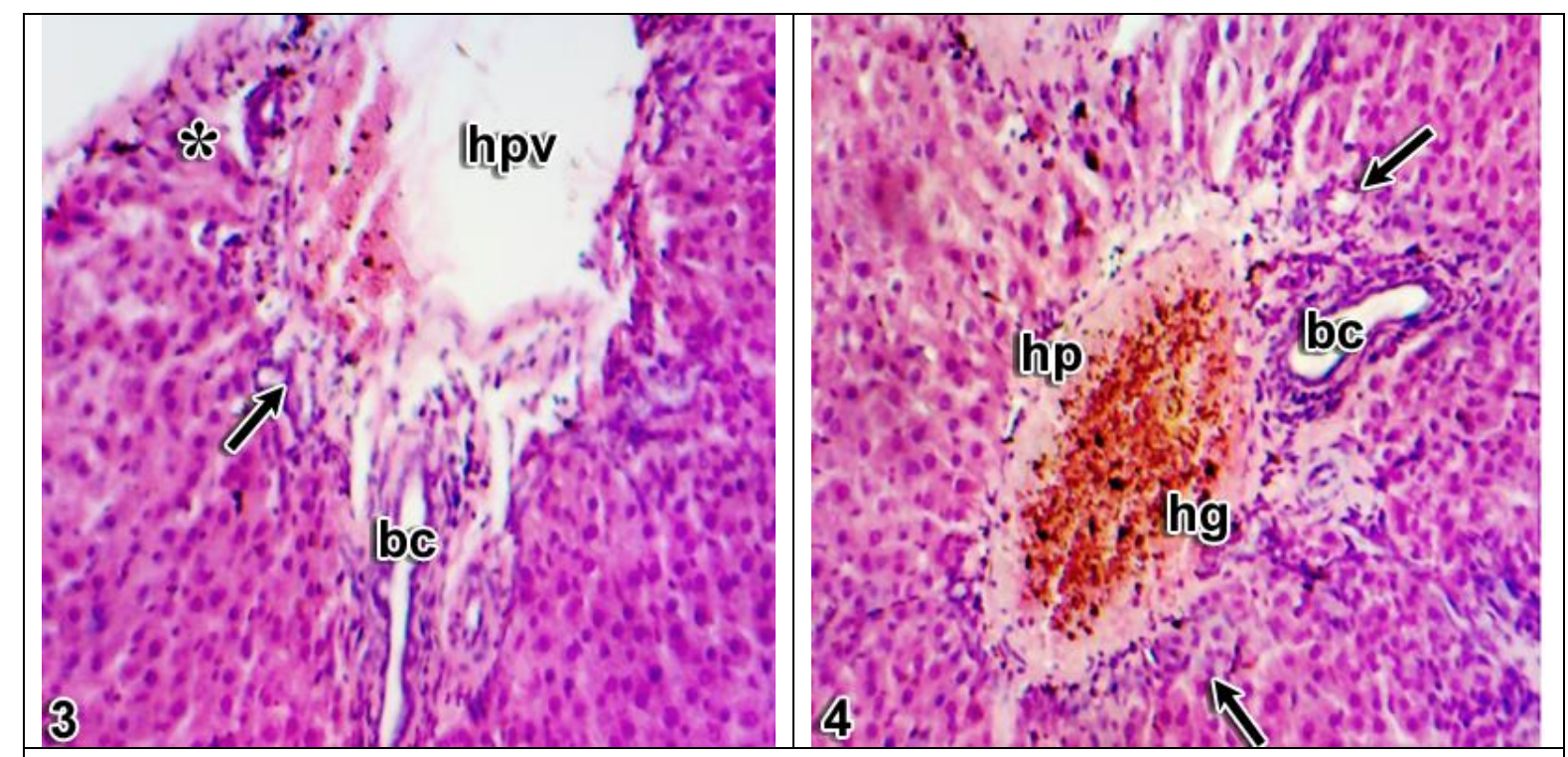

3\&4: Showing dilated hpv which contained haemolysed RBCs, elongated and thickened walls of bile canaliculi (bc) thickened arterial wall $(*)$, increased lymphocytic infiltration $(\rightarrow)$ in and around the portal area, nucleated RBCs (R), pyknotic nuclei in some hepatocytes and delaminated and ruptured endothelial lining of the hpv. 


\section{Effect of crowding ....}

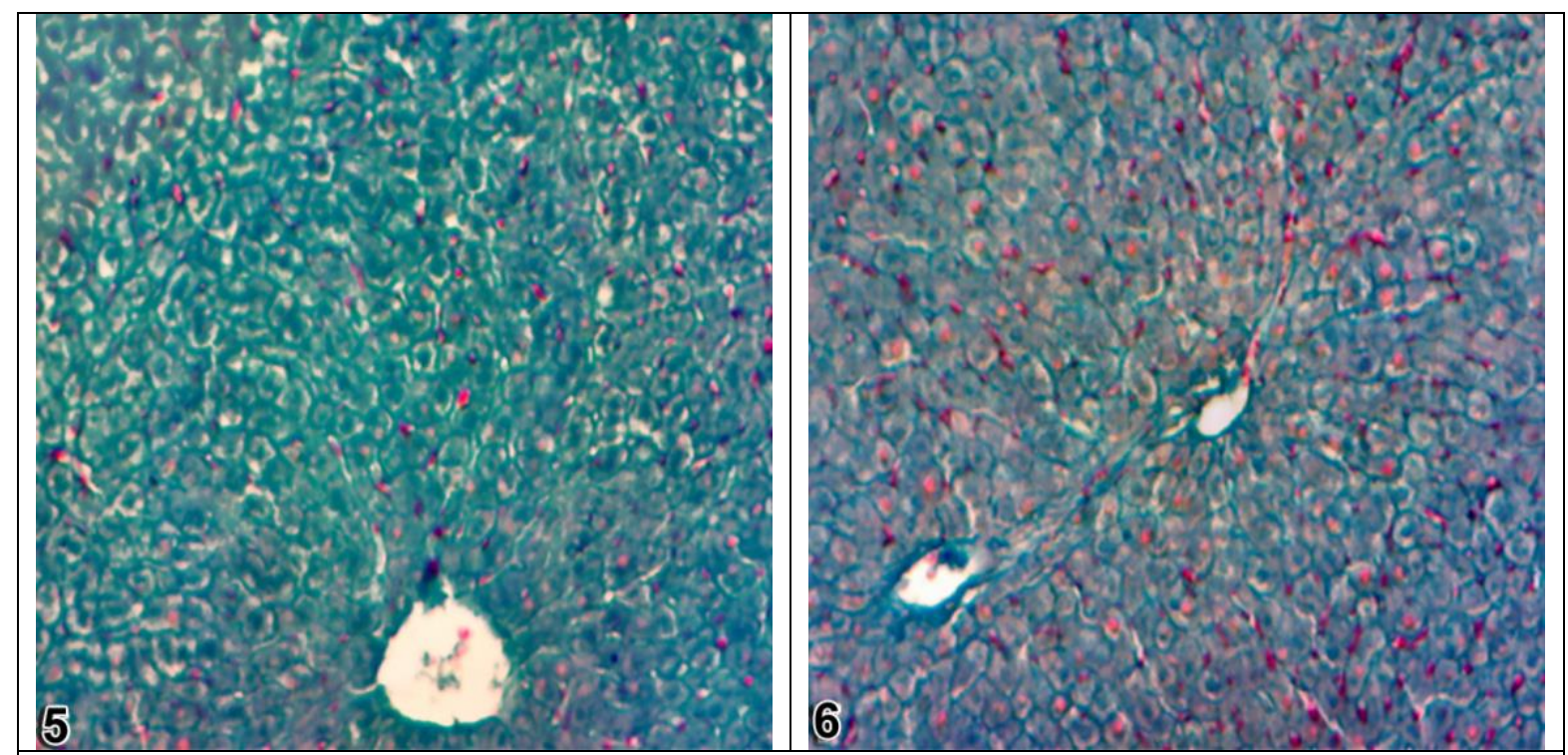

Figs.(5\&6) Showing normal distribution of collagen fibers in the liver tissue of a control female rat. (Mallory'strichrome stain $\times 100$ )

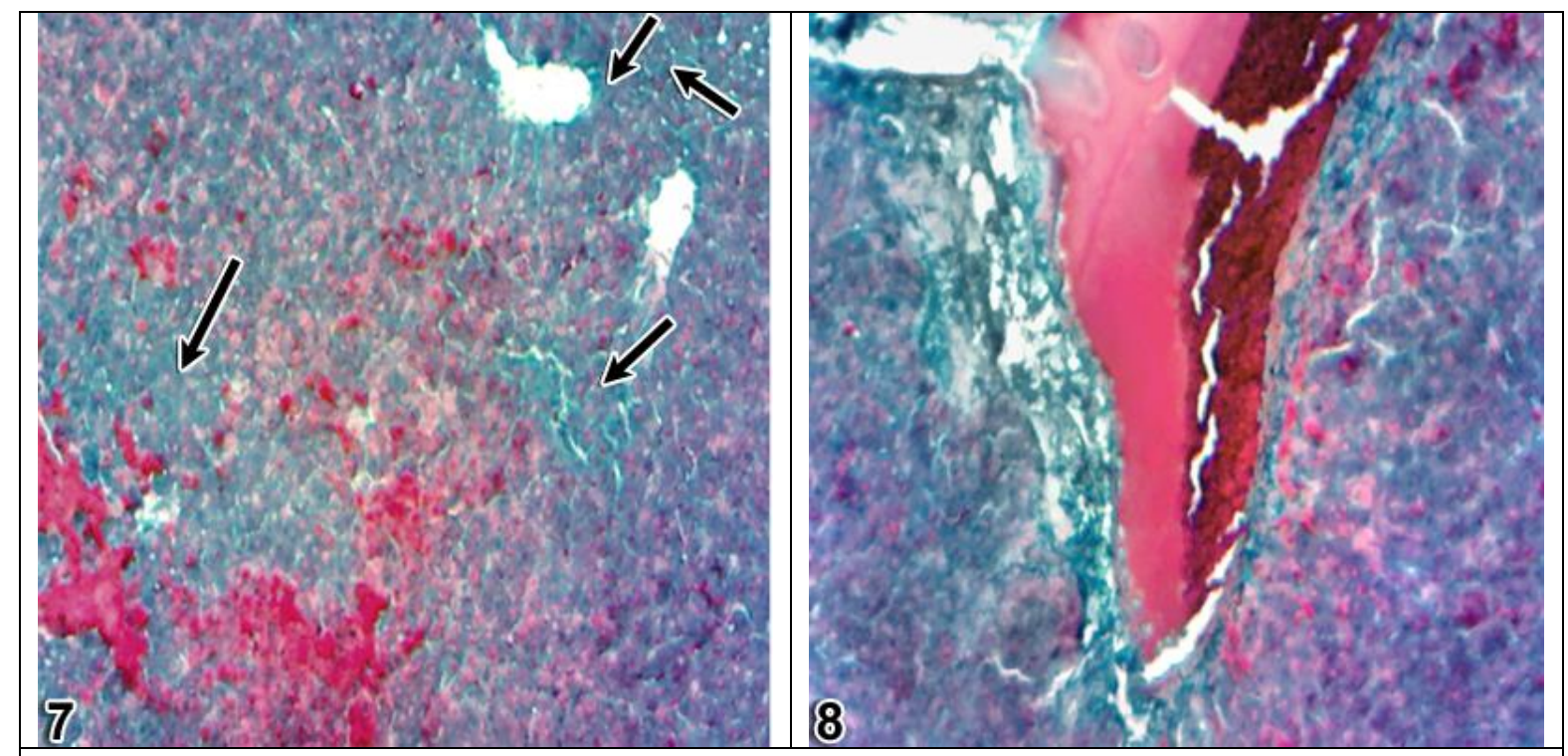

Figs. (7-8): Showing collagen fibers in the liver tissue of a rat exposed to crowding stress Notice: highly increased collagen fibers in the central area in and around the portal area, haemolysed RBCs accepted red color and so pools of RBCs which occupying dilated sinusoidal spaces.

(Mallory's trichrome stain $\times \mathbf{1 0 0}$ ) 



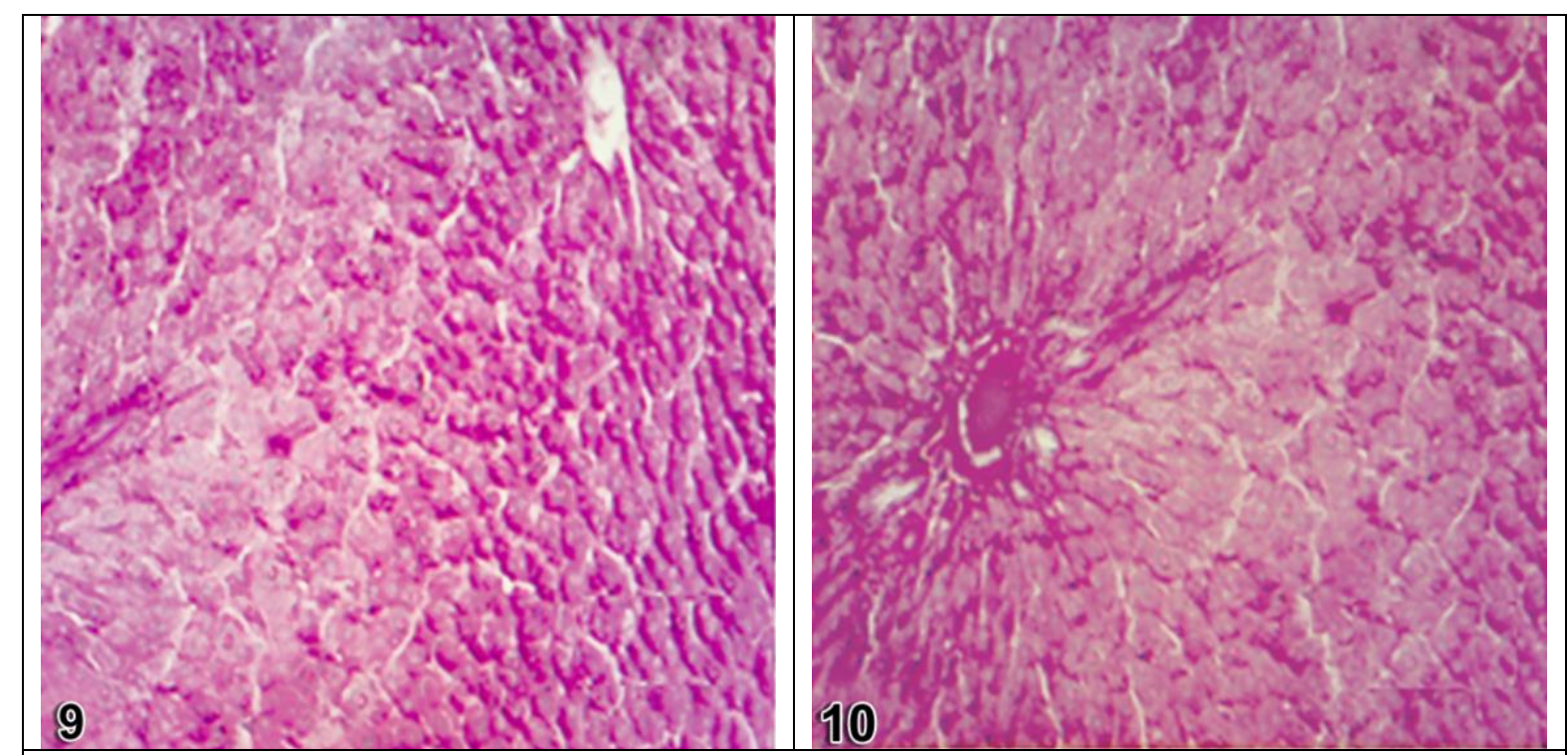

Figs.(9\&10)Showing normal distribution of PAS +ve materials in the liver tissue of acontrol rat in the central and portal and areas appeared less stained $\rightarrow) \quad(\mathbf{P A S} \times \mathbf{1 0 0})$

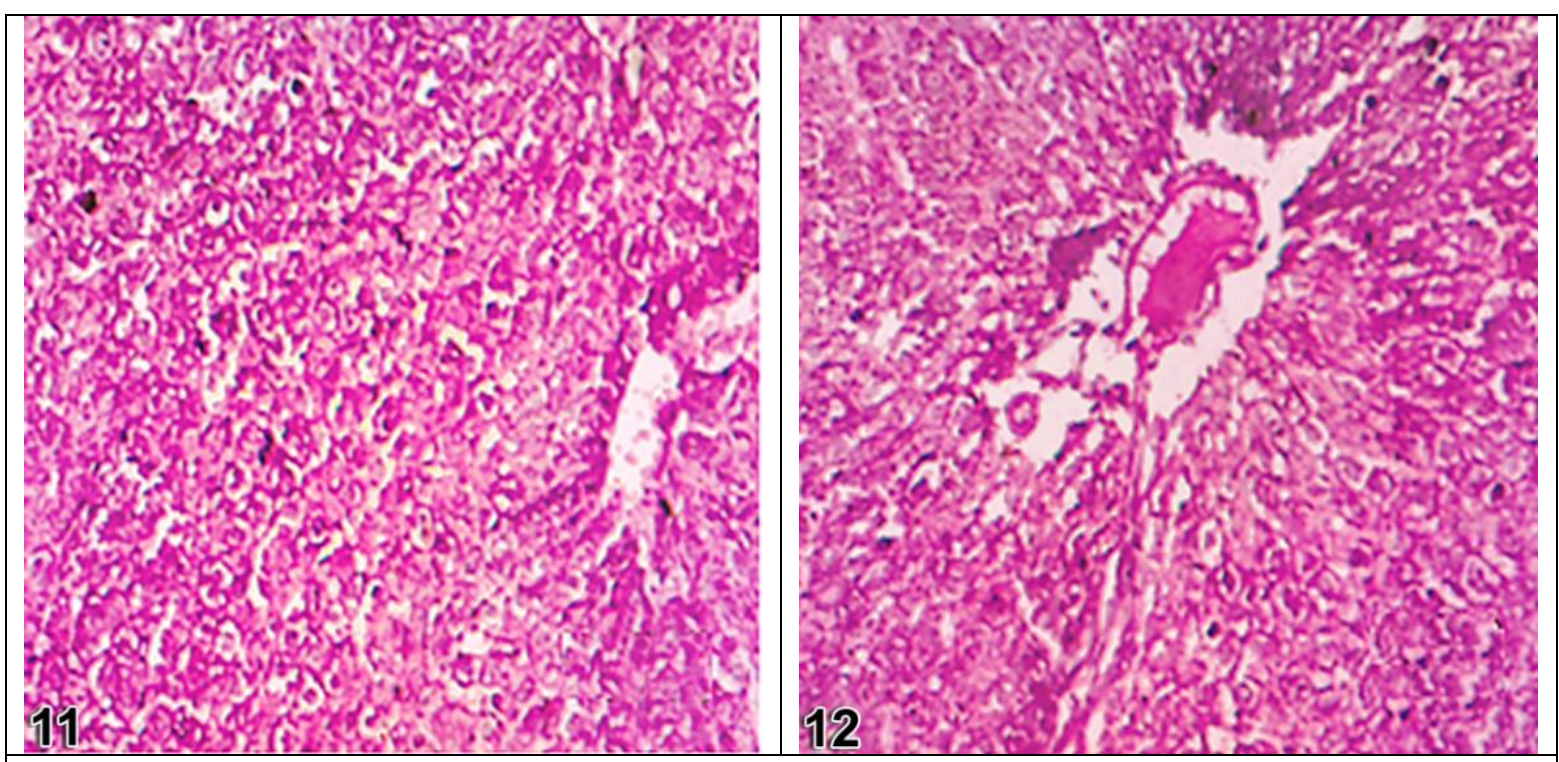

Figs. (11-12): showing highly decreased PAS +ve materials in hepatocytes and the portal area of the liver tissue of a rat exposed to crowding only.

Notice that haemolysed RBCs inside the hpv accepted homogenous red color. (PASx100) 


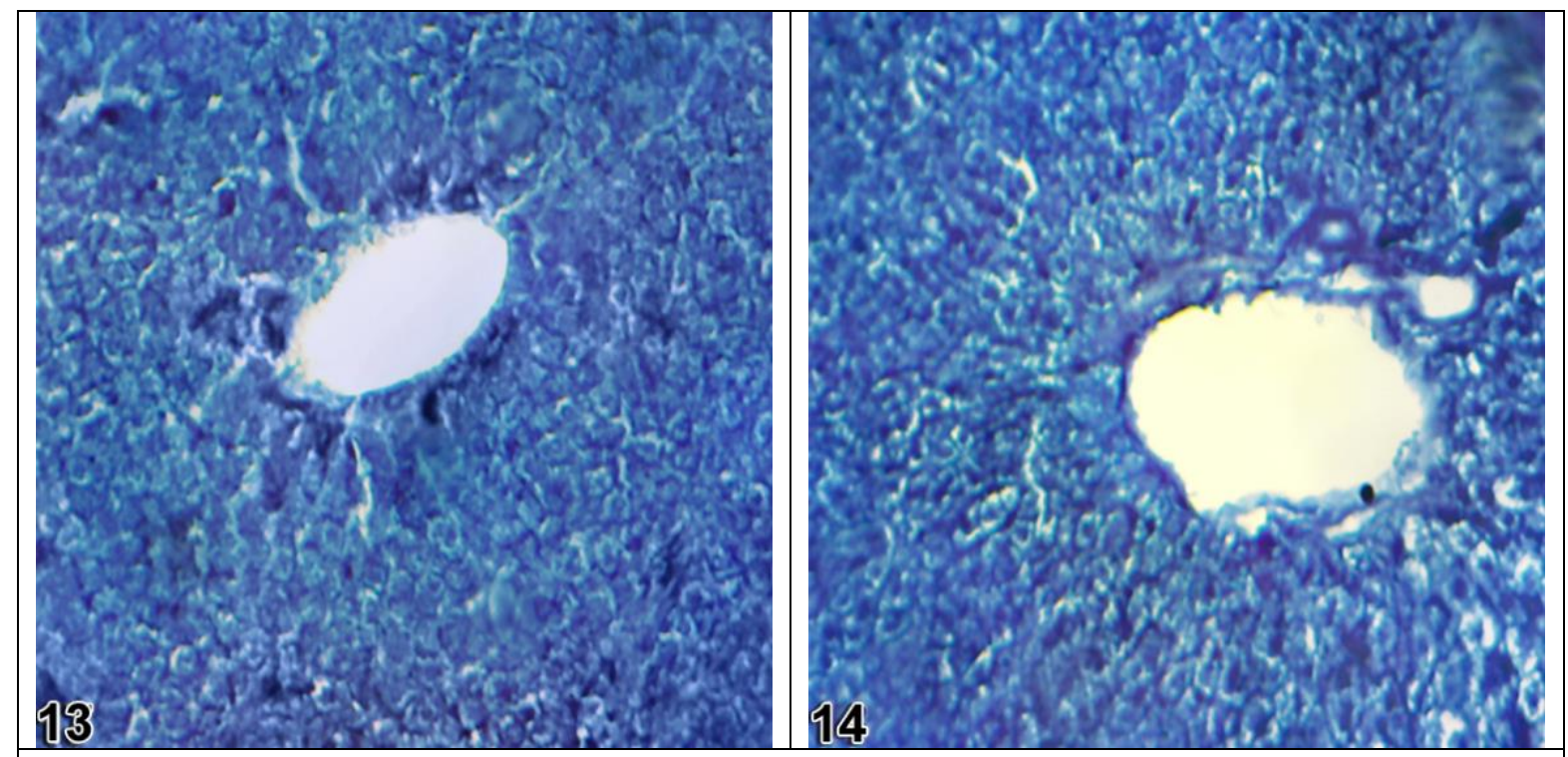

Figs.(13\&14) Showing normal distribution of total protein in hepatocytes, blood vessels and bile canaliculi in the liver tissue of a control rat. (Mercuric bromophenol bluex100)

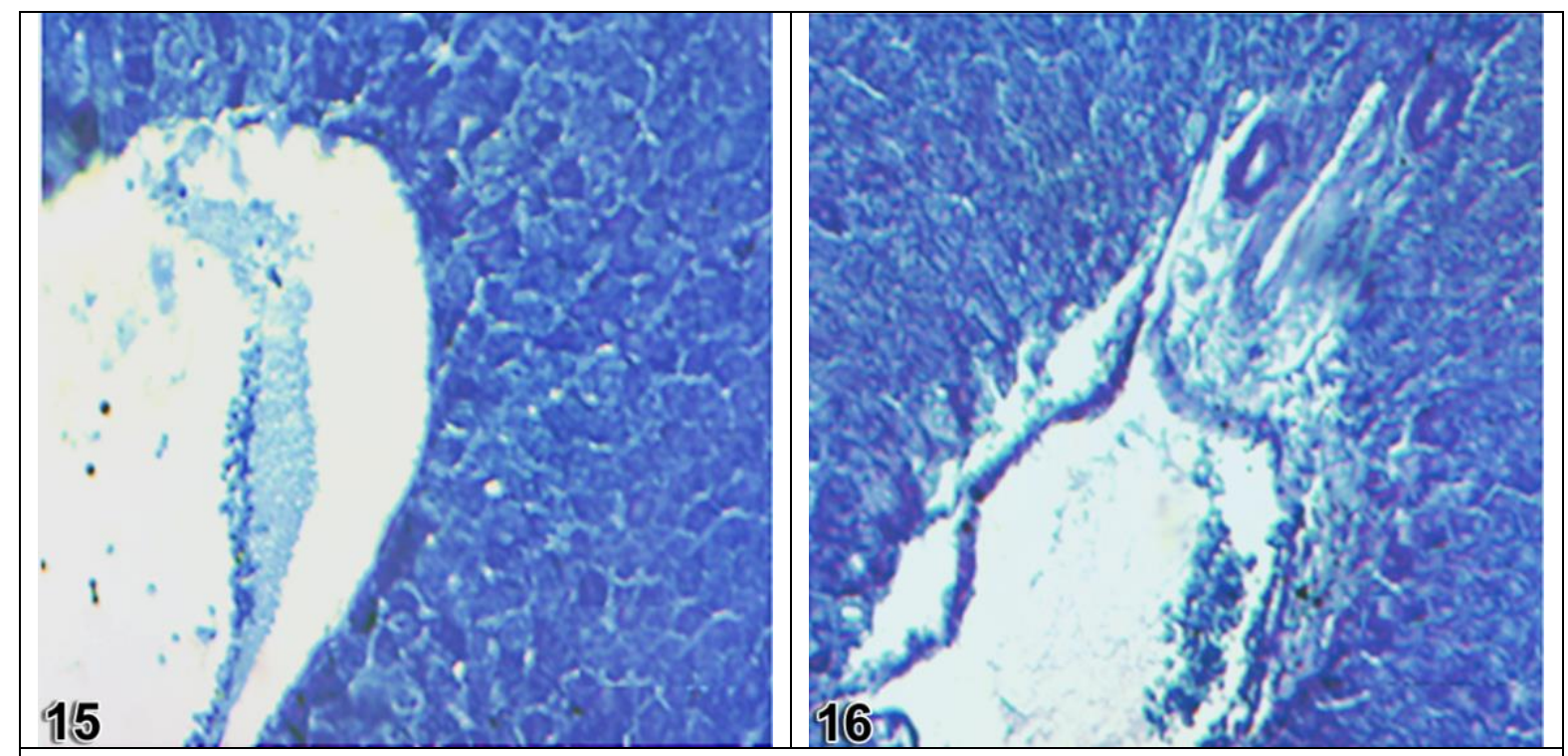

Figs. (15\&16): showing the central and portal areas of the liver tissue of a rat exposed to crowding with thickened connective tissue surrounding the portal area. Decreased stain affinity of total protein in walls of bile canaliculi, but, increased stain affinity was demonstrated in the thickened arterial walls. 


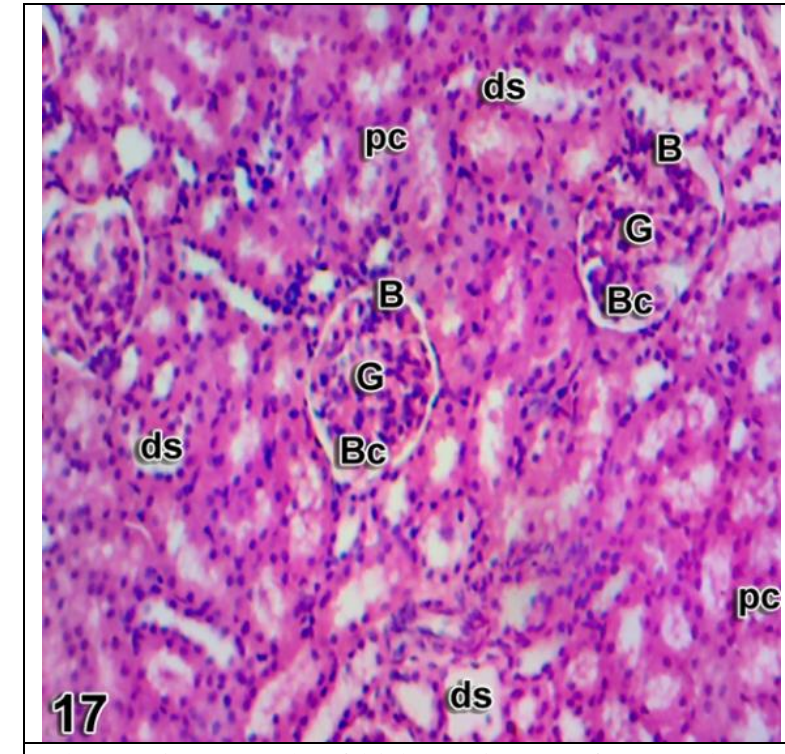

Photomicrograph of kidney tissue of control and treated rat

17-Showing kidney tissue of a control rat Notice. Malpighian's corpuscle with Bowman's capsule (B), Bowman's space (BC) glomeruli(G),distal convoluted tubules(ds) and proximal ones $(\mathrm{pc})$.

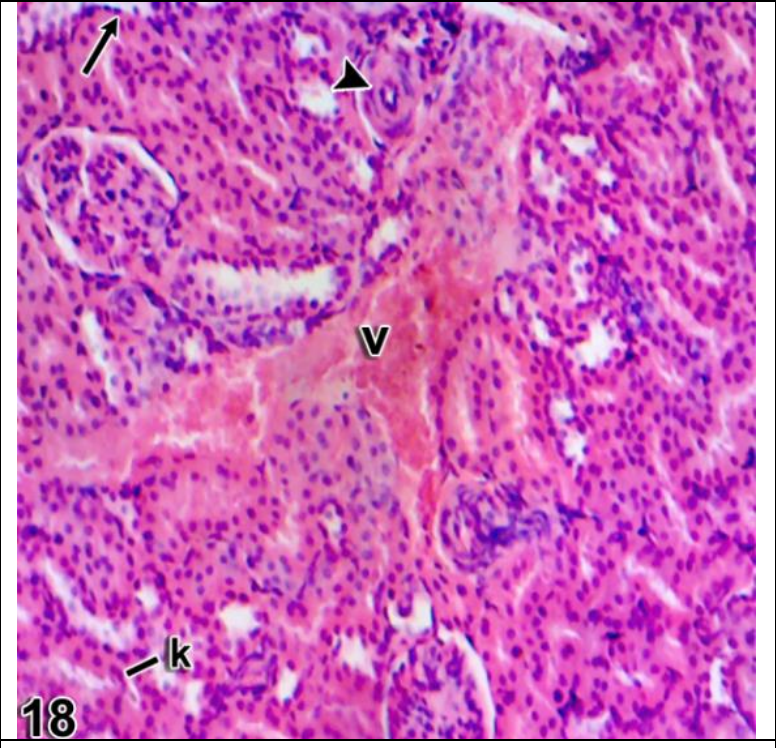

18-Showing kidney tissue of a rat exposed to noise stress.

Notice: many dystrophic changes which include: highly atrophied glomeruli $(\mathrm{G})$ with many pyknotic nuclei $(\rightarrow)$, faintly stained cells and nuclei of the proximal and distal convoluted tubules, wide lumena of the distal convoluted tubules, ruptured brush border of the proximal highly thickened arterial wall with branched and corrugated wall of the congested vein $(\mathrm{V})$

(Hx\&Ex100)

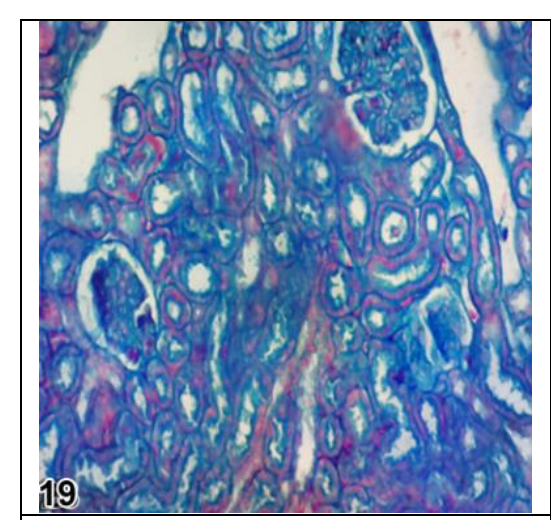

19: Showing thin collagen bundles supporting walls of the blood vessels, proximal and distal C.T, blood capillaries and Bowman's capsules of kidney

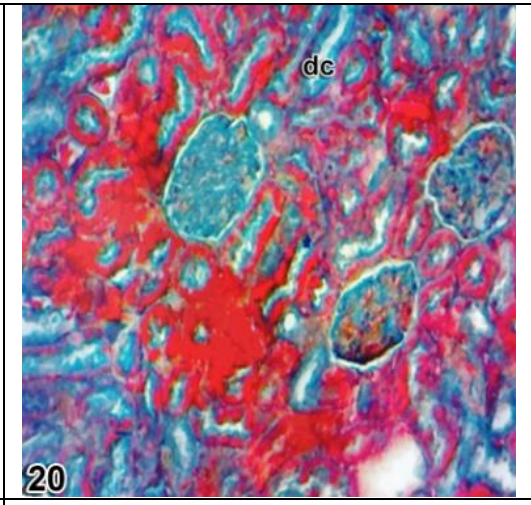

20: -Showing highly increased collagen fibers in the walls of the distal convoluted tubules (dc) and inside the glomeruli . Common fibrosis was detected

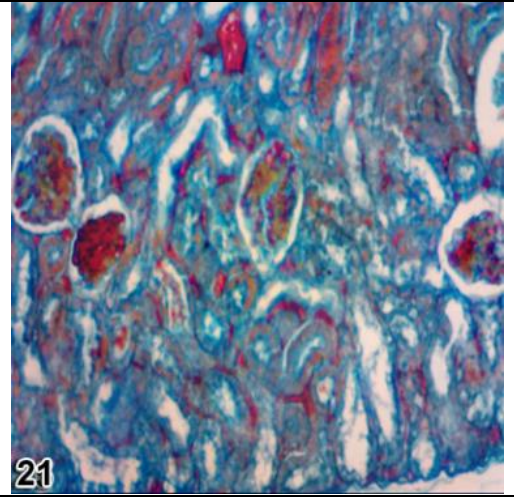

21: - Showing increased collagen fibers in between and around cells of the convoluted tubules and the Bowman's capsule of the kidney of a rat 


\begin{tabular}{|l|l|l|}
\hline $\begin{array}{l}\text { tissue of a control rat. } \\
\text { (Mallory's trichrome stain } \\
\text { x100) }\end{array}$ & $\begin{array}{l}\text { in most proximal C.T and } \\
\text { numerous brightly stained } \\
\text { hemorrhagic areas in the kidney } \\
\text { tissue of a rat exposed to } \\
\text { crowed stress. (Mallory's } \\
\text { trichrome stain x100 }\end{array}$ & $\begin{array}{l}\text { exposed to crowed and treated } \\
\text { with the drug. (Mallory's } \\
\text { trichrome stain x100) }\end{array}$ \\
\end{tabular}

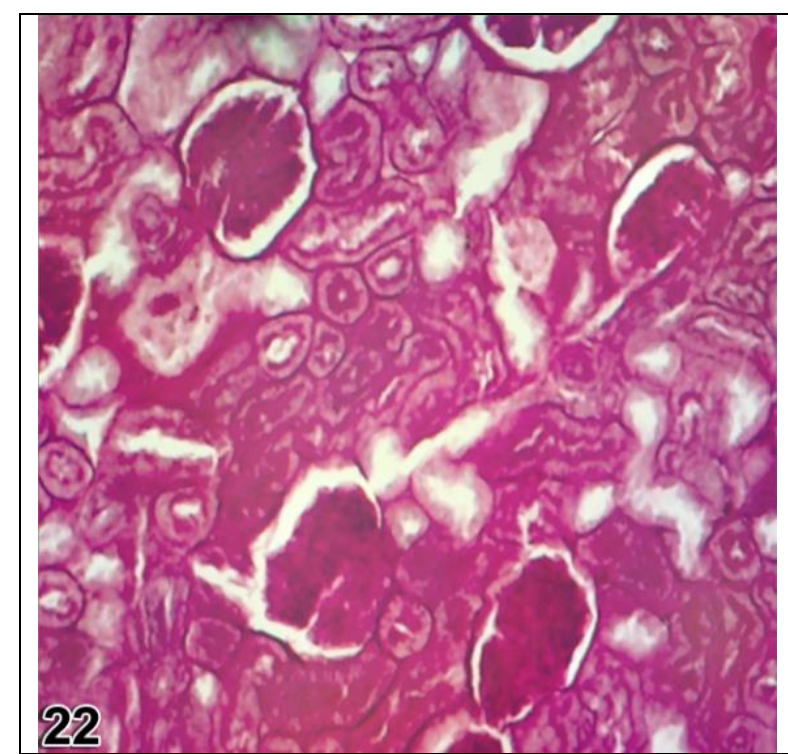

22- Showing normal distribution of polysaccharides in the kidney cortex of a control rat. deeply stained glomeruli, Bowman's capsules ,brush border of The proximal C.T and cells of the distal C.T, but cells of the proximal ones were less stained. (PASx100) .

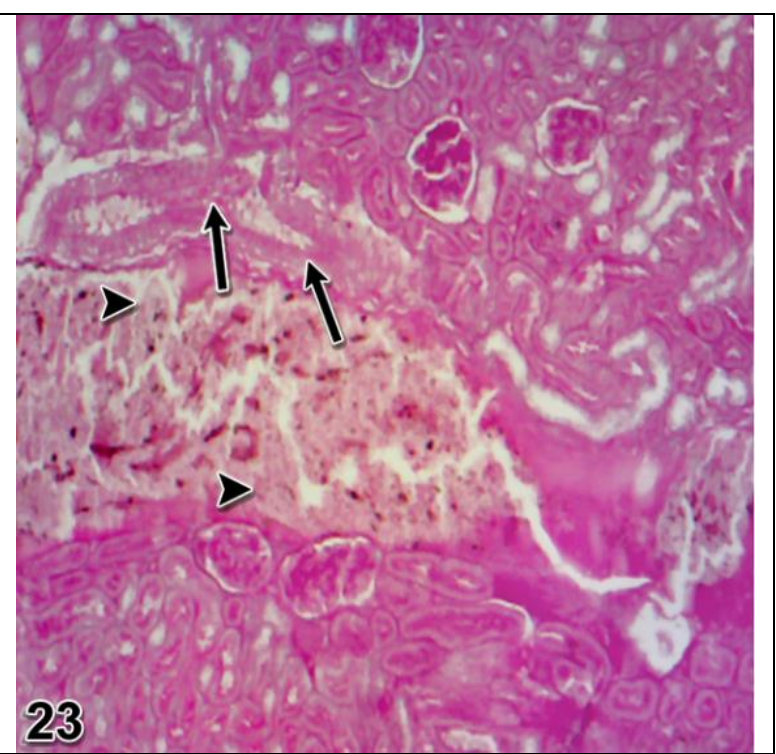

23: Showing distribution of polysaccharides in the kidney cortex of a rat exposed to crowded . moderately stained tunica media and adventitia of highly elongated and distorted renal artery $(\rightarrow)$, faintly to moderately stained endothelial lining of the vein $(<)$ which contained poorly stained haemolysed RBCs. (PASx100) 


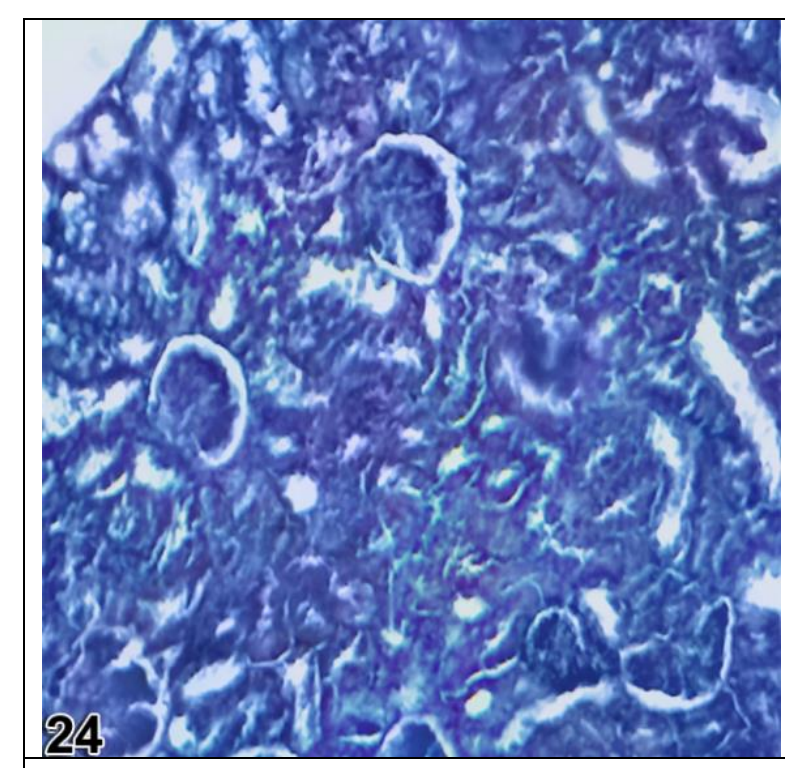

24: Showing normal distribution of total protein in the kidney tissue of a control rat.

Deeply stained glomeruli, cells of the proximal and distal convoluted tubules with less stained brush border. (Mercuric bromophenol blue x100)

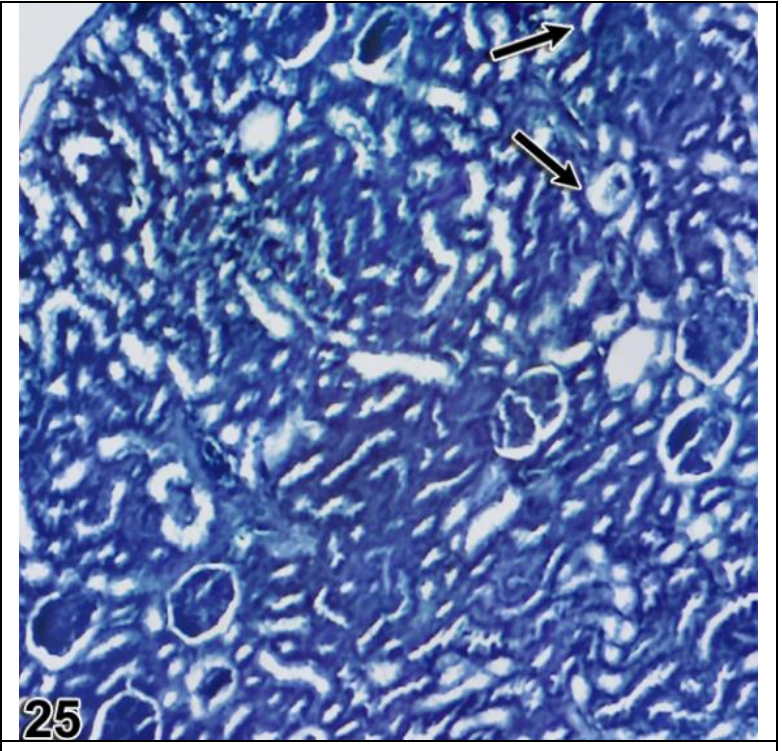

25: Showing total protein in the kidney tissue of a rat exposed to crowded stress.

Some atrophied glomeruli were deeply stained, while some of them were poorly stained $(\rightarrow)$, some convoluted tubules were faintly stained.

(Mercuric bromophenol blue x100)

\section{Discussion}

\section{1-Percentage of body weight change:}

Long-term administration of neuroleptics causes body weight gain which leading to obesity, which affects the general health of the patient and interferes considerably with treatment compliance (Awerman, 2010).The present results revealed that Sulpiride significantly increased body weight gain in adult female rats $(\mathrm{p}<0.01)$ in comparison with control group. This may be due to the action of Sulpiride which mainly interacts with dopamine D2-D3 receptors in the brain (Romero, 2008). Hyperphagia may be mediated by blockade of $\mathrm{D} 2$ receptors in the lateral perifornical hypothalamus (Cyr,2009).

In 2008, Romero ,reported that the atypical agents as Sulpiride increased body weight gain and adiposity in female but not in male Wistar rats .

The results of the present study on rats showed a significant decreased in the percentage of body weight gain of rats after exposed to crowding stress this may be because chronic exposure to crowding stress decreases body weight and food intake ( Marcelo et al .,2007) .

\section{2-serum glucose:}

The present results revealed that glucose significantly increased when rats exposed to crowding in adult female rats $(\mathrm{p}<0.01)$

The hyperglycemia in female rats under crowding stress may be related to stress hormone particularly cortisone, glucagon , and epinephrine which act synergistically both to increase glucose production and to reduce glucose clearance with hyperglycemia (Radahmadi et al,.2006). The hyperglycemic effect of stress may be also due to sympathoadrenal stimulation which may cause a concomitant increase in glucagon level (Tanck et al., 2002).Stress hyperglycemia may be also due to stimulation of hypothalamic noradrenergic activity and hepatic glucose output. So, if the central noradrenergic activity had been inhibited, the stress hyperglycemia also inhibited (Fevolden $\boldsymbol{e t}$ al., 2002). Corticosterone, as one of the stress hormone can also lead to increase blood glucose. (Sissel et al., 2005). 


\section{3-Liver functions test:}

Liver is a target organ and primary site of detoxification and is generally the major site of intense metabolism and is therefore prone to various disorders as a consequence of exposure to the stress of extrinsic as well as intrinsic forms. Liver plays important role in metabolism to maintain energy level and structural stability of body (Guyton and Hall,2002). The primary role of the liver in the metabolism is detoxification and disposition of foreign substance ( Boorman et al.,1990).

The present study indicated highly significant increase $(p<0.01)$ in serum alanine transaminase (ALT) and serum Gamma-gluttamyl transferase (GGT) activities in rat exposed to crowding , crowding + drug. Liver affection during stress is of great value because the corticoids are normally metabolized and destroyed in the liver. The increase Gamma-glutamyltransferase (GGT) and (ALT) showed an intimate relation to the cell damage and necrosis and/ or increased the permeability of the cell membrane (Boorman et al.,1990). The observed increase activity of serum ALT and GGT in the present work may be attributed to excessive release of such enzymes from the damaged liver cells into the blood circulation ( Behrman et al., 1992).

\section{4-Kidney functions test:}

The present study showed significant increase $(p<0.05)$ in serum creatinine in rat exposed to crowding, crowding + drug . The abnormal out comes in the present study could have resulted from kidney function impairment such as generation in the poroximal convoluted tubules (Senior, 2009).

Matsumoto et al.( 2009) recorded an increase in creatinine serum in rat exposed to crowding stress which may be due to increase catabolism in muscle and tissue that appear to act as a stimulus to synthesis of more serum creatinine.

According to Andrey(2010) crowding stress causes hyperthyroidism which is one of the disease characterized by disturbances creatinine metabolism. Consequently it is of interest that hypothyroidism also associated with reduced kidney transamidinase activity. It may be that the effect of hyperthyroidism on kidney transamedinase is actually mediated by the increase level of blood creatinine which occur in the disease.

\section{3-Protein profiles:}

The present study showed increase in serum total Protein \& Globulin in rats exposed to crowding . and a decreased in Serum A/G ratio in female rats. Martinez et al. (1992) mentioned that in crowding stress produced a non proportional changes in protein efficiency ratio and protein productive value.

The increase in total serum protein may be due to increase in secretion of stress hormone particularly corticosteroids. Corticosteroids increase both the plasma protein and liver protein, this may be carried out by increasing, the rate of breakdown of extra hepatic protein, making increase quantities of amino acids available in the body fluid. This allows the liver to synthesize increased quantities of hepatic cellular protein and plasma proteins . Crowding stress may also act through hormonal change which may alter the balance between tissue protein and circulating amino acids (Blumenthal $\boldsymbol{e t}$ al.,2000).

\section{4-lipid profile:}

The present results revealed that plasma lipid significantly increased when exposed to crowding stress in adult female rats .Plasma lipid response to stress varies from stressor to other according to severity and combination of more than stressor (Willis et al.,2009) .The alteration in plasma lipid depends on the type and severity of stress as well as several individual characteristics, such as heightened neuroendocrine or autonomic reactively to stressors. So, stress may influence lipid concentration and metabolic thought variety of physiological and behavioral mechanisms ( Blumenthal et al.,2000).

Radahmadi et al. (2006) demonstrated that all type of plasma cholesterol levels 
increased in response to stress particularly LDL-C which constitute the bad type of cholesterol. Brenna et al. (1992) mentioned that stress induced increase in plasma level of cholesterol and triglyceride. Willis et al.(2009) mentioned that stress induced an elevation in serum total cholesterol concentration which may persist through the recovery period, increased triglyceride level , fatty acids, LDL-C and HDL-C .

The rate clearance of lipid also increases in some stressful situation. Meraihi et al.(1990) observed that Hyperlipidamia under crowding stress may be due to decreased insulin secretion. Insulin has an antagonistic effect upon catecholamine mediated lipolysis . Sulpiride drug ameliorated the effect of crowed of most measured parameter.

\section{The histopathological and histochemical}

\section{studies:}

Treatment of rats with sulpiride showed no detectable histological or histochmical changes in the liver tissue, but increased lymphocytes in and around the portal areas were be observed. Sulpiride is a selective dopamine D2 antagonist with antipsychotic and antidepressant activities. In spite of the normal architecture of liver tissue observed in rats treated with sulpiride in the present study some authors detected many side effects post -treatment with it (Ruther et al., 1999; Cohen, 2004; Toprak et al., 2005) .Exposure to crowding showed vacuolated hepatocytes with enlarged nuclei of them and the endothelial lining of the blood vessels with increased lymphoctic infiltration. Dilated hepatic portal veins and sinusoidal spaces with increased kupffer cells where also detected. Results of the present study showed congested hepatic portal vein with enlarged nuclei of their endothelial lining. These results are in accordance with those of Kaplan and Wheeler (1983). They stated that principal effect of stress on the liver is related solely to changes in hepatic blood flow specifically, this hypothesis suggested that emotional stress leads to vasospasm and centrilobular hypoxia and ultimately to liver damage however, as the broader physiological effect of the mediators of the stress response have become better understood. Highly affected endothelial lining of blood vessels of the liver tissue post- exposure to stress for a long time were observed by Fraser et al. (1995). ) .It was suggested that stress influenced hepatic blood flow by inducing vasospasm and centrilobular hypoxia, leading to liver damage (Chida et al.,2006) . Increased risk factors for malignant transformation of cirrhotic lesions in Japanese patients exposed to stresses were detected by Tanaka $\boldsymbol{e t}$ al. (1998). In 2004, Steel et al., stated that stress may account in part for rapid hepatocarcinoma development. Glaser $\boldsymbol{e t}$ al. (1985) proved the association between rotational stress and carcinogen damage. Positive correlation between psychosocial stress and liver injury, inflammation and fibrosis were reported by Vere $\boldsymbol{e t} \boldsymbol{a l}$. (2009). In the present study sings of improvement were observed in liver tissue of rats treated with the drug and exposed to crowding, but some haemolysed RBCs were still detected inside the hepatic portal vein with increased kupffer cells. Sulpiride which belongs to narcoleptics class interferes with cerebral dopaminergic nervous transmissions stimulating a dopaminomimetic effect (George et al., 2001). According to Chida et al.(2006) the vagus nerve from the brain to the liver when stimulated with anti- stress therapy (hypnosis, mediation, acupuncture) may actually improve or reduce the negative effect of stress on the liver. Highly increased collagen fibers were detected in and around the portal areas, dilated sinusoidal spaces and walls of blood vessels of the liver tissue exposed to crowding . Horn et al. (1985) declared that the presence of collagen in the presinusoidal spaces might affect the blood supply to liver cells and would reduced the exchange of metabolites, perhaps causing hepatocellular dysfunction and necrosis. Liver of rats treated with the drug and crowded showed normal appearance of collagen fibers. Polysaccharides were poorly stained in hepatocytes of the central areas of the liver tissue of rats exposed to crowding, but increased stain affinity of PAS +ve materials was detected in the portal areas and thickened arterial walls. Haemolysed 

RBCs inside the blood vessel acquired pale red color. the present study showed that $\mathrm{RBCs}$ acquired deep red coloration and this may be due to high content of carbohydrates in them .In this respect Junqueria and Carneiro(2003) stated that RBCs contain 10\% carbohydrates of their weights ; this may explain the increased stain affinity of polysaccharides inside the congested sinusoidal spaces and hemorrhagic areas. Decreased polysaccharides in liver tissue postexposure to crowding observed in the present study may be due to failure of hepatocytes to synthesize or store glycogen and may be also a result of maculation and degeneration observed in the hepatocytes. Rats treated with the drug and exposed to crowding showed normal PAS+ve materials in liver tissue of them and this indicates the protective effect of sulipirde against the drastic effect of this type of stress.

Normal total protein was observed in the hepatic tissue of rats treated with the drug with a slight increase in the portal area due to increased lymphocytes. Highly reduced total protein was detected in hepatocytes of the central areas with deeply stained hemorrhagic areas in liver tissue of rats exposed to crowding compared with the control group. The arterial walls were deeply stained. Decreased total protein observed in the present study may be due to the degenerative changes noticed in the liver tissue or may be also due to increased reactive oxygen species production which harm the mitochondria (Cogger et al., 2004).In rats exposed to crowding and treated with the drug normal stain affinity of total protein was realized in hepatocytes of the central area ,but they were faintly stained in the portal area with deeply stained arterial walls. In this respect, the histological damage might result from an increase in the process of lipid proxidation and decreased activity of antioxidant enzymes of the body with the consequent damage of cellular membranes (El Habit et al.,2000).

In 2008, Katzung stated that the sulpiride is a drug with relatively minor adverse effects .It has been regarded by some psychiatrists as the safest neuroleptic. Exposure of female rats to crowding caused many deleterious changes in the kidney cortex. Highly thickened arterial walls were detected with haemolysed RBCs inside these arteries with numerous hemorrhagic areas in between the convoluted tubules .Increased kupffer cells and ruptured brush borders of proximal convoluted tubules with atrophied glomeruli were also observed. Hypertension is an established risk factor for congestive heart failure long-term exposure to pressure overload induces left ventricular remodeling and cardiac hypertrophy, subsequently resulting in heart failure (Zhang and Kaufman, 2008). Reactive oxygen species (ROS) increased in response to mechanical stress, this increase in ROS induces apoptosis (Katzung, 2008), and contributes to the progression of heart failure( Samson et al .2005) . Effects of crowding on the immune status have also been reported (Archana and Namasivayam, 2000). Thus, crowding exposure contributes to genesis and manifestation of several multifactor diseases, of chronic annoyance, and permanent behavioral alterations. According to Agarwal (2005) stresses led to oxidative stress which contributes to renal injury .This injury seems to be predominantly localized to the renal proximal tubules and this injury was realized in the destructed brush borders of proximal convoluted tubules observed in the present study. The previous results discuss the injury observed in the glomeruli and cells of proximal convoluted tubules in the kidney cortex of rats exposed to crowding in the present study. Sings of improvement were observed in the kidney cortex of rats exposed to crowding and treated with the drug, Zhang and Kaufman( 2008)declared that increased size and number of kupffer cells reflect clearly the active defense mechanism against the toxic substances and proliferation of the kupffer cells is achieved in order to engulf hepatic cell breakdown products. Normal distribution of collagen fibers was observed in the kidney cortex of control rats and those treated with the drug, but highly increased collagen fibers with common fibrosis were detected post exposure to crowding . Increased collagen 
fibers observed in the present study may lead to rapid healing. This opinion was discussed by Zhang $\boldsymbol{e t}$ al. (2006) who reported that increased collagen may lead to rapid healing, rapid differentiation of cells and appearance of a new network of blood vessels, Increased collagen fibers were still noticed in kidney cortex of rats treated the drug and exposed to crowding . Normal distribution of polysaccharides was observed in kidney cortex of rats treated with the drug compared with the control group, but some cells of convoluted tubules were less stained. Highly decreased polysaccharides were observed in the kidney cortex of rats exposed to crowding this injury may be responsible for decreased total protein observed in the present study. Thickened and deeply stained arterial walls observed in the present study was also detected by another authors $(\mathbf{G u} \quad$ et al.,1998;Agrwal,2005) .They stated that exposure to stress induces oxidative stress and this leads to increased free radical production which cause hypertrophy in the vascular smooth muscle cells and hypertrophy of arterial walls and increased mortality . Decreased protein content due to oxidative damage has been reported by Nikolaos et al. (2004) and Samson et al .(2005) .

\section{References}

Abicht K, El-SamaloutiV, Tunge W, Kroll M, LuthH and Treskes $M$ (2001): Multicenter evolution of new GGT and ALP reagent with new reference standardization and determination of $37^{\circ} \mathrm{C}$. Clin. Chem., 39 : 301308.

Agarwal M D ( 2005) : Hypertension in chronic kidney disease and dialysis : pathphysiology and management. Cardiol. Clin., 23: 237-248.

Andrey V (2010): Endoplasmic reticulum stress in proteinuric kidney disease Department of Medicine MCGill University Health centre.Montreal Quebec, Cananda. 77:187-193.

Archana R and Namasivayam A (2000): Effect of Ocimum sanctum on noise induced change in neutrophil function, $\mathrm{J}$. Ethnopharmacol.,73: 81-85.
Awerman L M (2010): Chronic Psuchlogical stress alters body weight and blood chemistry in European starlings. Comparative Biochemistry and Physiology, 156:136-142.

Behrman R E, Kliegman R M, Newlson W E and VaughanV C (1992): Metabolic disorders In: Nelson Text Book of pediatrics . fourteenth (Ed) ,W.B Lonan Saunders Co, Hicowt Brace Jovanvich, Inc.Pp.: 411-416.

Benyo $Z$, Szabo $\mathbf{C}$ and Kova $A \quad P$ (2007):Prevention of the hemorrhagic hypotension-induced hepatic arterial vasoconstriction by L-arginine and naloxone. Shock, 11:342-346 .

Boorman G A ,Eustis S L,El-Well M R and LeinigerJ $R$ (1990): Pathology of the Fisher Rat. Reference and Academic press Harcourt Brace J0vanoich .Publishers: San Diego ,New York , Boston , London ,Sydney, Tokyo and Toronto, Pp: 114-117.

Blumenthal M, Busse W $\mathbf{R}$ and Goldberg A (2000): The Complete Commission monographs. Therapeutic guide to Herbal Medicnes .Boston ,M.A. Integrative medicines communication: 80-81

Brenna F X Job R, Watkins $\mathbf{L} \mathbf{R}$ and Maier S F (1992): Total plasma cholesterol levels of rats are increased following only three sessions of tailshoch. Life-Sci., 50(13): 545-550.

Burtis C A, Ashwood E R and Burns D E (2006): Clinical Chemistry and Molecular Dignostics. Philadephia, Pa:W.B. Sanders . $4^{\text {th }}$ ed. Pp.:549-587.

Chida Y ,Sudo N, and Kubo C (2006): Does stress exacerbate liver diseases. Gastroenterol Hepatology,21:202-208.

Cleopatra S P (2007): Chronic restraint or variable stress differently affect the behavior, corticosteron secretion and body weight in rats. Physiology .Behavior Publishers: San Diego ,New York .90:29-102.

Cohen D (2004):Atypical antipsychotics and new onset diabetes mellitus Medical, Science Monitor., 47:160-165.

Cogger V C, Muller M, Fraser $R$ and khan J (2004): The effect of oxidative stress on the liver sieve. J.of Hepatology , 41: 370-376.

Cyr N E (2009): Identifying hormonal habitation in filed studies of stress. Gen .comp. Endocrinol. 161: 295-303.

Drury $R$ and Wallinigton E (1980): Carleton's Histological Technique, $4^{\text {th }}$ Ed. Oxford. Univ. Press, New York, Toronto. Pp.:115-119.

El Habit O, Saada H, Azab K, Abdel Rahman $M$ and El Malah D (2000): The modifying effect of beta carotene on gamma radiation-induced elevation of oxidative 
reactions and genotoxicityin male rats. Mut. Res., 466: 179-190.

Fevolden S E, Roed K H and Ftalested K T (2002): Selection response of cortisol and lysozyme in rain bow tout and correlation to growth. Aquaculture, 205:61-75.

Fraser R, Dobbs B R and Rogers G W (1995):Lipoproteins and the liver sive, the role of the fenesterated sinusoidal endothelium metabolism arthrosclerosis. And cirrhosis. J.Hepatology, 21:863-874.

George I, Ramesh k, Stem $\mathbf{R}$ and Chandrakasan G (2001): Dimethyl nitrosamine-induced liver injury in rats: the early deposition of collagen. Toxicology, 156: 129-138.

Glaser $R$, Thorn B E, Tarr K L and Kiecolt-Glaser J K (1985): Effects of stress on methyltranseferase synthesis: an important DNA repair enzyme . Health psychol.,4:403412.

Gu J W,Anand V and Shek E W (1998): Sodium induces hypertrophy of cultured myocardial myoblasts and vascular smooth muscle cell. Hypertension ,31:1083-7.

Guyton A C and Hall J E ( 2002): Text Book of Medical, Physiology, 9th ed. Prism Book (Pvt) Ltd.,Bangalore, India. Pp:.11481151.

Horn T, Jung J and Christoffersen $P$ (1985): Alcoholic liver injury: early changes of the Disse spase in acinar zone. Liver, 6: 301-310.

Junge W, Wilke B, Halabi A and Klein G (2004): Determination of reference intervals for serum creatinine, creatinine and creatinine clearance with an enzymatic and a modified taffe method Clin. Chim. Acta., 344: 137-148

Junqueira $L$ and Carneiro $\mathbf{J}$ (2003): Basic Histology Text \& Atlas. $10^{\text {th }}$ ed., The McGraw-Hill Companies,USA.Pp.:160-165.

Kaplan M H and Wheeler W F (1983): Stress and diseases of the upper gut .J.of Egypt.Hosp.Med. 50: 225-227.

Katzung B G (2008) : Basic and Clinic Pharmacology, Appleton \& Lange, Lepanon, , pp.: 448-460.

Knight $\mathbf{J}$ A, Anderson $S$ and Rawie $\mathbf{J} M$ (1972): Chemical basies of sulfophosphovanilin reaction for estimation total serum lipid.Clin. Chem., 18:199-202.

Kytzia H (2005): Reference intervals for GGY according to the new IFCC $37^{\circ} \mathrm{C}$ reference procedure. abstracts: Congress of Clinical Chemistry and Laboratory Medicine, 103: 6-8.

Marcelo T M, Marin F, Marecelo T, Fabio C and Cleopatra S P (2007): Chronic restraint or variable stress differently affect the behavior, corticosteron secretion and body weight in rats.

Health Psychol.,90:29-102.

Martinez F J, Garcia M P, Canteras M and Zomora S (1992): Simultaneous effect of initial weight, initial noise temperature and concentration on the nutritional use food by rainbow trout. Pharmacopychiatry, 40: 105110.

Matsumoto S, Hanai $H$.Matsuura $H$ and Akiyama Y (2009): Creatol, an oxidative product of creatinine in kidney transplant patients, as a useful determination of renal function : A, preliminary study. Transplantation Proceedings,38:2009-2011.

Mazia D, Brewer P and Alfert M (1953): The cytochemical staining and measurement of protein with mercuric bromophenol blue .Biol.Bull.,104: 57-67.

Meraihi Z, Lutzo O, Scheftal J $M$ and Bach A C (1990): Decreased lipolytic activity in tissue during infection and inflammatory stress. Nutrition, 7(2) : 93-98.

Nikolaos $P$, George $Z$, Nikolaos $T$ P,Christos D G , Fevronia A and Nikolaos A M (2004): Thiol redox state (TRS) and oxidative stress in the mouse hippocampyus after pentylenetetrazol - induced epileptic seizure. Neurosci. Lett., 357: 83-86.

Paget G $E$ and Barnes $J \quad M$ (1964):Evaluation of drug activity in Pharmaceutics Laurence and Bacharach eds ., Vol.1 Academic press. NewYork.

Panzani D I ,Zicchino a and Taras P (2011): Sulpiride use of dopamine antagonist sulpiride to advance first ovulation in transitional mares .Theriogenology, 75: 138-143.

Pearse A (1977) : Histological Theoretical and Applied $3^{\text {th }}$ ed vol I.Churchill Livingstone ,London 112-115.

Radahmadi M, Shadan F, Seied $M$ and Nasmimi A (2006): Effects of stress on exacerbation of diabetes mellitus, serum glucose and cortisol levels and body weight in rats Pathophysiology, 311: 51-55.

Romero L M (2008): Daily and Seasonal variation in response to stress in captive, startings, corticosterone. Gene Comp Endocrinol.,119: 52-59.

Ruther E, Degner D and Manzel U (1999):Antidepressant action of sulpiride.Results of aplacebo- controlled double - $\quad$ blind trial. Pharmacopychiatry,32:127-135.

Samson T, Sheela D, Ravidran $M$ and Senthilvelan A (2005): Effect of noise stress on free radical scavenging enzymes in brain. Environmental toxicology and pharmacology, 20:142-148. 
Schumann G (2002): Procedures for the measurement of catalytic activity concentrations of enzymes at $37^{\circ} \mathrm{C}$. Procedure for the measurement of catalytic concentration of aspartate amino transferase. Clin .Chem. Lab., 40(7): 725-733.

Senior R (2009): Stress Test for the Kidney . Department of Nephrology All India institute of Medical Sciences New Delhi. 110-129.

Sissel J , Aastveit A, Peter A and Tortesen C (2005): Effect of stress on growth, cortisol and glucose levels in nondomesticated Eurasian Perch and domesticated rain bow trout (oncorhynchus mykiss). Comparative Biochemistry and Physiology, 141:353-358.

Snedecor G W and Cochran W G (1980): Statistical Method .United State University Press,Lowa, London Pp: 59-60.

Steel J, Carney M, Carr B I and Baum A (2004): The role of psychosocial factors in the progression of hepatocellular carcinoma .Med .Hypotheses , 62:86-94.

Stein E A and Myers G L (1995): National cholesterol education program recommended for triglycerides measurement. Ameta-analysis of 27 trials.Arterioscler. Thromb., 41: 14211426.

Sugiuchi (2005): History of development and technical details of the homogenous assay for HDL and LDL cholesterol .Eng .J.Med., 1: 411.

Tanaka K,Sakai H , Hashizume $M$ and Hirohata T (1998): Along -term follow -up study on risk factors for hepatocellular carcinoma among Japanese patients with liver cirrhosis . J.Cancer Res .,89:1241-1250.
Tanck M W T,Claes T, Bobenhuis $H$ and Komen J (2002): Exploring the genetic background of stress using isogentic progenies of common carp selected for high or low stress-related cortisol response, Aquaculture 204: 419-434.

Tietz, N.W. (1995): Clinical Guide to Laboratory Tests. 3ed ${ }^{\text {rd }}$ Philadelphia Pa: W.B. Saunders Company Londan , Pp: 130-131.

Tietz, N.W. (2006): Clinical Guide to Laboratory Tests. Chemistry Saunders Co., London $4^{\text {th }}$ ed. Pp : 44-51.

Tomoyuki H (2004): The effect of noise on the health of children. J. Nippon. Med. School, 71:5-10.

Toprak O , Mustafa C, Erosoy R, Uzum A and Omer $O$ (2005): New- onset type II diabetes com and acute renal failure in a patient treated with sulpiride . Nepherol .Dial Transplant., 20:662-665.

Vere C C, Streba $\mathbf{T}$ andIonescu $\mathbf{G}$ (2009):Psychosocial stress and liver disease status. World Gastroenterol ., 28:2980-2986.

Wiilis C,Armario A, and Piganini H (2009): Cholesterol and triglyceride concentration in rat plasma after stress .Pharmacol .Biochem.Behav.,31(1):75-79.

Zhang $K$ and Kaufman R J (2008): From endoplasmic -reticulum stress to the inflammatory response .Nature , 454: 455-462. Zhang D, Xu Z, Chiang A, Lu D and Zeng Q (2006): Effect of GSM $1800 \mathrm{MHz}$ radiofrequency $\mathrm{EMF}$ on DNA damage in Chinese hamuster lung cells. Zhonghuo Nei. Ke. Za. Zhi., 36(3): 183-186. 


\title{
تأثير الازدحام و العلاج بعقار السلبرايد على بعض المعايير الفسيولوحية

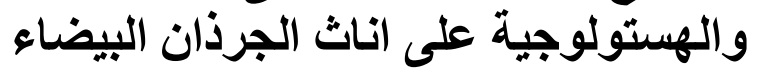

\author{
فاطمة عيد, ايمان جمال الدين عزت هلال و نعمة محمود طه عطية

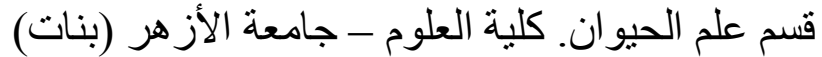

يعتبر الازدحام من أكثر المؤثرات العصبية على الإنسان لذا تهدف هذه الدراسة إلى توضيح

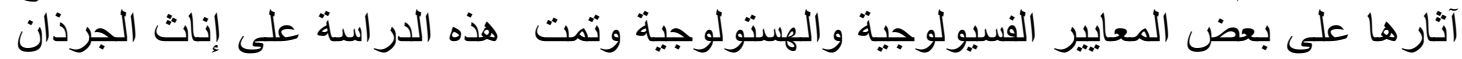

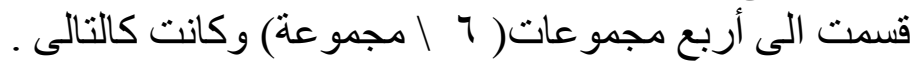
المجمو عة الأولى:- استخدمت كمجمو عة ضابطة . المجمو عة الثانية :- مجمو عة عولجت بعقار السلبر ايد فقط.

المجموعة الثالثة :-مجمو عة الجرذان التى تعرضت للزحام فقط يوميا لمدة ب يوما.

المجمو عة الر ابعة :-مجمو عة الجرذان التى تعرضت للزحام و وعولجت بعقار السلبر ايد.

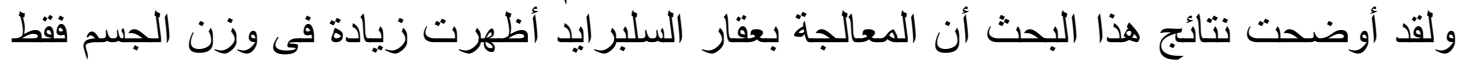

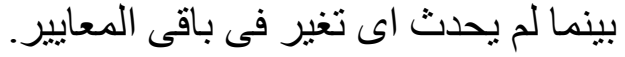

أما عند التعرض للزحام فقد كانت هناك زيادة إحصائية فى كل من : نسبة السكر فى الدم -

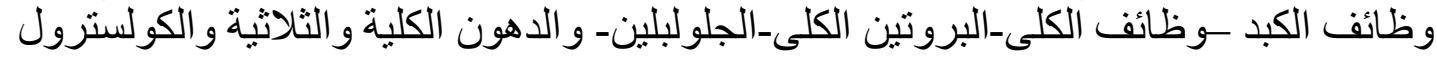

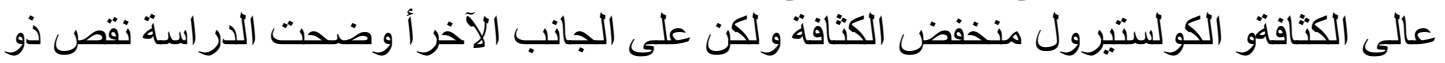
دلالة إحصائية فى وزن الجسم ونسبة الألبومين و الجلوبلين ولقد إتضح أن هذا العقار حسن

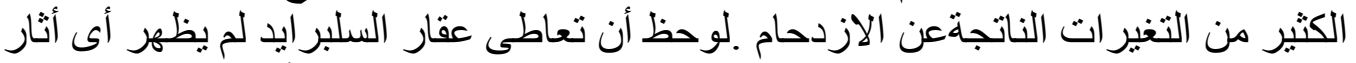

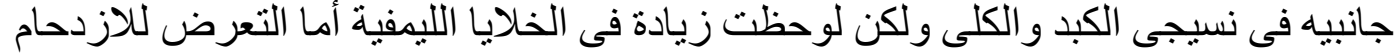
فقط أظهر تغير ات هستولوجية وكميانسيجية عديدة بالنسيج الكبدى و الكلوى و أظهرت الكئ المعاملة

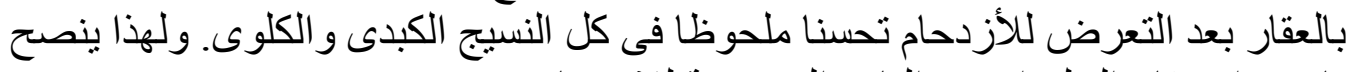

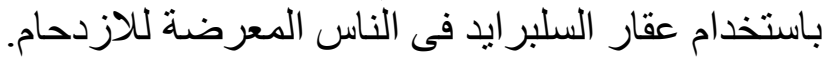

